\title{
Seasonality, Resource Stress, and Food Sharing in So-Called "Egalitarian" Foraging Societies
}

\author{
JOHN D. SPETH \\ Museum of Anthropology, University of Michigan, Ann Arbor, Michigan 48109
}

Received April 17, 1989

\begin{abstract}
Most discussions of food sharing among so-called "egalitarian" hunters and gatherers implicitly assume that, because all adult members of a group participate in the network of sharing, all must therefore be receiving portions of more or less equivalent nutritional worth. This assumption is questioned and five basic points are raised: (1) because fat is not uniformly distributed over the carcass of an animal and because it is depleted sequentially when an animal is stressed, certain individuals may receive nutritionally inferior portions of meat, with potentially serious health consequences for the recipients during seasonal or interannual periods when other food resources are in short supply; (2) even when sharing is quantitatively and nutritionally equitable, food taboos may block certain individuals from access to meat and/or fat, particularly children, women at critical stages in their reproductive life, and the elderly (however, in the case of pregnant women, such food taboos and seemingly inequitable sharing practices may have positive as well as negative consequences for the health and survivorship of the fetus or newborn infant by keeping maternal protein consumption below about $20 \%$ of total calories and by reducing the mother's risk of exposure to potentially teratogenic substances that may accumulate in animal tissues); (3) skilled hunters may acquire nutritionally more valuable parts than do other males by "snacking" at kill sites and through differential sharing; (4) food-sharing practices and food taboos vary widely among foragers, and this diversity may contribute to observed differences among groups in fertility and infant mortality patterns; and (5) the focus of anthropologists on the sharing of food, especially meat, as opposed to the sharing of a broad spectrum of social, political, economic, and sexual rights and privileges, is an overly narrow and potentially misleading perspective. In closing, the paper briefly discusses the utility of the term "egalitarian," concluding that the concept, by conflating ideology with actual behavior, may obscure rather than enhance our understanding of the origins and adaptations of foraging societies. 1990 Academic Press, Inc.
\end{abstract}

\section{INTRODUCTION}

Food sharing, particularly sharing involving meat from larger mammals, is widely held to be one of the principal hallmarks of so-called "egalitarian" hunter-gatherer or "band" societies (e.g., Isaac 1978; Lee and DeVore 1968; Service 1971). Almost every ethnographic study of 
foragers mentions the occurrence of some form of food sharing, and most comment on the importance of meat from larger mammals in these exchanges. The reciprocal give and take of hunted foods as well as other resources, assured among egalitarian foragers by powerful social sanctions, is thought to play a crucial role in maintaining amicable and cooperative relations among the society's members (see Knauft 1987 for observations on the frequency and causes of homicides among foragers). Sharing may also serve to counterbalance the differential success of particularly skilled hunters (e.g., Hill and Hurtado 1989; Howell 1986:164), and may be vital in preventing some individuals or families from hoarding to the detriment of others (Lee and DeVore 1968). And, of course, food sharing may provide foragers with a safety net or means of pooling risk during seasonal or interannual periods of local scarcity (Cashdan 1985; Gould 1981, 1982; Wiessner 1982; Winterhalder 1986). Sharing of food, especially meat, is believed by many anthropologists to be so basic a part of the forager way-of-life that archaeological evidence for its apparent emergence more than one-and-a-half or two million years ago in the PlioPleistocene has been taken as one of the first clear signs of true "humanness" (Isaac 1978).

It is not my purpose here to argue against the overall importance of food sharing among contemporary or prehistoric hunter-gatherers. Nor do I disagree in any fundamental way with current views that see sharing as a key factor in forming and maintaining social bonds or in pooling risk. Instead, I wish to show that our views of food sharing in egalitarian foraging societies often are overly normative and idealistic in assuming that, because all adult members participate in the network of sharing, all must therefore be receiving portions of more or less equivalent nutritional worth. In other words, I question the assumption that equality in the right to participate in the act of sharing necessarily implies equity in the nutritional benefits that accrue from sharing (see also Flanagan 1989:248).

In brief, this paper makes five basic points. First, from the nutritional perspective, the mere sharing of meat among a series of participants, even if it is shared in roughly equivalent amounts, in no way assures that the shared portions are of equivalent nutritional value. The fact that the fat content of meat may vary significantly from part to part within a single animal, and the fact that the total body-fat reserves of an animal may fluctuate dramatically from season to season, almost guarantee that shared portions of meat will differ, at times markedly, in their food value, unless the participants make explicit efforts to distribute the fat independently of the lean tissue. If sharing practices fail to distribute the fat in an equitable manner, then in situations of seasonal or interannual resource stress, when other sources of calories such as carbohydrates are in short 
supply, there may be serious nutritional consequences for some of the participants.

Second, even when the amount and nutritional worth of the shared foods (including fat) appear to be relatively equitable, the presence of taboos often blocks certain members of the society-usually women, but often also children and the elderly-from consuming these foods (Spielmann 1988, 1989; Rosenberg 1980). As shown by Spielmann $(1988,1989)$, these taboos often are enforced at precisely the times in an individual's life when the food might have its greatest nutritional benefit (e.g., meat or animal fat being taboo for children during critical growth periods, or for women at puberty or when they are pregnant or nursing). However, food taboos and seemingly inequitable food-sharing practices that block pregnant women from access to meat may have exceedingly complex nutritional underpinnings with important positive as well as negative consequences for the health and survivorship of the fetus and newborn infant. On the negative side, being denied access to meat and fat may lower the mother's caloric intake to the point where the growth and health of the fetus are compromised. On the positive side, such taboos and foodsharing practices may actually enhance the health and survivorship of the fetus, by keeping the mother's protein consumption below about $20 \%$ of total calories, and by limiting her risk of exposure to potentially toxic or teratogenic substances sometimes present in animal tissues.

Third, there is growing evidence to suggest that many foraging groups have hunters who are more skilled, and hence more successful, than others (e.g., Bailey 1988, Barnard and Woodburn, 1988:17; Høygaard 1940:65; Kaplan and Hill 1985a; Siskind 1973). These fortunate hunters may have differential access to the nutritionally most valuable portions of an animal (e.g., tongue, brain, kidney and other internal organ fat, and marrow fat) directly at the site of the kill (i.e., "snacking"); or, in the sharing process they may have rights to more valuable parts because they made the lethal strike, or because they owned the weapon (e.g., spear or arrow) or facility (e.g., net or trap) used to take the prey. In addition, because patterns of meat redistribution among many foraging groups are highly stylized and "traditional," with named anatomical parts invariably going to specific individuals, better hunters or their families consistently may receive carcass portions of higher food value. These observations suggest that the commonly espoused view of egalitarianism in foraging societies, which holds that all individuals of the same sex and age cohort have essentially equal access to life-sustaining resources (see discussions in Fried 1967; Begler 1978; Flanagan 1989), may be inappropriate or misleading. The term must therefore be used with great caution, and then perhaps only with reference to ideological matters. To avoid confusion, it 
might be better to drop the term altogether as a typological categorization of forager societies.

Fourth, while some foragers display inequitable patterns of food sharing and food taboos, these are by no means uniform features of all hunting and gathering societies. In fact, what is striking about forager sharing practices and food taboos is the degree to which they vary from group to group, in form, timing, and intensity. Not surprisingly, as our data base on hunter-gatherers improves, anthropologists are also finding significant differences between groups in stature, body weight, daily and seasonal work patterns, energy budgets, and fertility and mortality patterns (e.g., Hill and Hurtado 1989; Hurtado and Hill 1987:184-185; Campbell and Wood 1988). The role of differing food-sharing practices and food taboos in these diverse foraging adaptations remains to be systematically and quantitatively documented and explored.

Finally, the emphasis that anthropologists place on the sharing of food, especially meat, as opposed to the sharing of a broad spectrum of social, political, economic, and even sexual rights and privileges, is an overly narrow perspective, one that may obscure rather than enhance our understanding of the origins and functioning of foraging (i.e., so-called "band" or "immediate return") societies, and particularly the processes by which such societies adapt to stressful situations and ultimately evolve into more complex systems (see de Waal 1989b).

\section{ANIMAL PHYSIOLOGY AND THE PROBLEMS OF LEAN-MEAT CONSUMPTION DURING PERIODS OF RESOURCE SHORTAGE}

Regardless of habitat, animals commonly face seasonal food shortages, and are forced to mobilize their stored body fat reserves (Speth 1983, 1987a, 1987b; Speth and Spielmann 1983). In temperate and northern latitudes, the principal time of stress occurs in late winter and spring, when animals may become fat depleted. In tropical latitudes, food stress generally is related to seasonal declines in precipitation rather than temperature, but the net effect again is loss of body fat (Sinclair 1974, 1975; Speth 1987a). Many tropical animals, for example most antelopes in the grasslands of East Africa, have very low fat reserves to start with, and at times of peak stress may have virtually none (Ledger 1968; Sinclair 1974, 1975). Reproductive activities also may lead to mobilization of fat reserves (Speth 1983). In females, this is most likely to occur during pregnancy and lactation. In males, fat depletion often is most severe during the rut. An animal's age and health status obviously also influence its physiological condition. Thus, very young and very old animals, as well as animals that are diseased or infested with parasites, may be extremely lean. 
Fat mobilization in most mammals occurs in a relatively fixed sequence, beginning with the back fat, then progressing to the fat deposits within the body cavity, and finally to the marrow fat reserves in the limbs and mandible (Speth 1983). Even the limb bones themselves are depleted in a relatively fixed order, generally beginning with the marrow fat in the humerus and femur and then progressing distally down the limbs. In some mammals, the front and rear limbs are depleted at different rates, although detailed sequences have been documented only in a few species (e.g., Brooks et al. 1977; Peterson et al. 1982; Ratcliffe 1980; Reich 1981; Sinclair and Duncan 1972). Fat in the marrow of the mandible is mobilized at more or less the same time as the deposits in the limbs, but the mandible retains moderate levels of fat even after the limb bones have been largely depleted (Speth 1983). In a severely stressed animal, the principal remaining fat deposits may be confined to the mandible, the distal limbs, particularly the phalanges, and the brain. Important deposits of lipids also persist in the cancellous tissue of the vertebrae.

Following the period of stress, fat reserves are replaced in the reverse sequence, beginning with the marrow deposits in the limbs and culminating, in well-fed animals, with replenishment of the subcutaneous deposits.

This ordered pattern of fat mobilization means that at any point during the period of stress, different parts of an animal carcass will have different amounts of fat. Moreover, the fatty acid composition differs from one fat deposit to another, and also varies with diet and season (Speth 1983, 1987a). The fatty acid composition in turn affects the taste, digestibility, essential fatty acid content, and overall susceptibility of the fat to rancidity (cf. Krehl and Barboriak 1960:530; Speth 1983, 1987a).

The amount of fat in meat is of considerable importance to hunters and gatherers (Speth and Spielmann 1983; Speth 1987a, 1987b; Jochim 1981:78-87; Hayden 1981). Fat makes foods taste good, and it conveys a feeling of satiety when one has eaten. Fat is also a critical source of fat-soluble vitamins and essential fatty acids. Moreover, fat is a highly concentrated source of energy, supplying more than twice the calories per gram than either carbohydrate or protein, and fat is more efficiently metabolized than protein (Mead et al. 1986; Guthrie 1975; Speth 1987a).

But there is another important reason why fat is critical to hunters and gatherers, particularly during times of stress. There appears to be an upper limit to the total amount of protein (animal and plant combined) that one can safely consume on a regular basis. This limit-best expressed as the total number of grams of protein per unit lean body mass that the body can safely handle-is about $300 \mathrm{~g}$ or roughly $50 \%$ of total calories (George F. Cahill, Jr., personal communication). Protein intakes above this threshold may exceed the rate at which the liver can metabolize amino acids, and the body can synthesize and excrete urea (see discussion in 
Noli and Avery 1988; Speth 1989; McGilvery 1983; but see also Buchanan 1988:60-64 and references therein), leading ultimately to hypertrophy and functional overload of the liver and kidneys, elevated, even toxic levels of blood ammonia, dehydration and electrolyte imbalances, calcium loss, micronutrient deficiencies, and lean tissue loss (McArdle et al. 1986:545; Whitney and Hamilton 1984:145; Cahill 1986:42; Hegsted and Linkswiler 1981; Miller and Mitchell 1982:115-116).

Many lines of evidence point to the existence of an upper limit to the total amount of protein an individual can safely consume on a sustained basis, but its precise nature, causes, and magnitude remain very controversial. Laboratory rats, often used as analogues in studies of human diet (see summary in Hill 1988), are able to adapt to diets that provide greater than $50 \%$ of the energy as protein, although the higher the protein content is above $35 \%$, the longer the adaptation time required (Alfred E. Harper, personal communication). Harper (personal communication; see also Harper and Peters 1989) makes the interesting observation that

\begin{abstract}
when rats are first offered a high protein diet their food intake decreases, their growth declines, water consumption increases very substantially but, after a period of adaptation, the rate at which they can metabolize amino acids from protein increases greatly. As this occurs, their food intake increases, their growth rate increases, and they seem to perform almost as well as those receiving a moderate amount of protein (Anderson et al. 1968). Liver and kidneys, organs intimately involved in amino acid metabolism and elimination of waste products from proteins, hypertrophy (Munro 1964). The adapted animals survive well, although there is some evidence that their longevity may be shortened. Interestingly, if rats that are well adapted to extremely high protein diets are offered an opportunity to choose between low and high protein diets, they will select from the two to obtain about $25-35 \%$ of their energy as protein and, over a short period of time, this usually declines to between $20-25 \%$ of energy as protein. (Peters et al. 1983)
\end{abstract}

Similar results were reported by Castonguay et al. (1982), who observed that genetically lean adult rats selected a dietary mix in which protein contributed slightly in excess of $30 \%$ of total calories. Donald et al. (1981) observed that adult rats fed diets containing $25 \%$ protein for 9 weeks were fatter than rats fed a diet containing the same number of calories but only 5\% protein. Finally, Burkhardt et al. (1982) observed increasing growth rates in rats the higher the protein content of the diet up to levels in which protein contributed about $25 \%$ of calories, although growth rates were highest at protein levels bclow about 10-15\% and fell off rapidly at higher levels (see also Mercer et al. 1981; Harper and Peters 1989).

Although studies of laboratory rats are interesting, their appropriateness for establishing protein needs and tolerances in humans is subject to question (cf. Hegsted 1978:62; Shorland 1988:170). Unfortunately, relatively few studies of high protein intakes have been conducted in humans, 
and the results are somewhat ambiguous. For example, Cheremin (1985) observed elevated levels of blood ammonia, as well as other deleterious effects, in diets in which protein provided only $25-30 \%$ of total calories. Regrettably, the duration of his study (only 10 days) was too short to observe whether the test subjects adapted over time to these protein intakes (see Oddoye and Margen 1979 for observations on adaptation). At the other extreme, Calloway and Margen (1968; see also Harper 1974b:158) observed no obvious ill effects in healthy male volunteers who consumed a purified diet in which protein provided up to $70 \%$ of total calories. Most studies with human subjects point to a safe upper protein threshold lying between these two extremes, on the order of $300 \mathrm{~g}$ or about 50\% of total energy (e.g., McGilvery 1983:791; Eaton and Konner 1985:287; Cahill 1986:42; McArdle et al. 1986:545). Interestingly, this value is in close agreement with the highest sustained protein intakes (up to about $45 \%$ of total calories) reported for traditional Eskimos, the most "carnivorous" human populations known, under normal (i.e., nonstressful) conditions (Draper 1977, 1980; Hфygaard 1940; Krogh and Krogh 1914; McClellan and DuBois 1930; McClellan et al. 1930; Mann et al. 1962; Sinclair 1953; Stefansson 1944, 1956).

The protein intakes seen in Eskimo diets exceed the highest sustained levels reported for hunter-gatherers and other "traditional" populations outside of the arctic, including East African camel and cattle pastoralists who traditionally subsist heavily or almost entirely on animal products. For example, the Northern Ache, foragers in the tropical forests of eastern Paraguay, consume a diet in which protein (mostly derived from meat) provides an average of $39 \%$ of calories (Hill and Hurtado 1989; Hill 1988:178). Turkana pastoralists in northern Kenya obtain about $80 \%$ of their per capita dietary energy from milk, meat, and blood. Nevertheless, only about $21 \%$ of their calories on average are provided by protein (Galvin 1985:iv; Little et al. 1988:724). During the dry season, generally a period of stress, their calorie intakes decline and the proportional contribution of protein may approach 30\% (Galvin 1985:184-194). Although data for the Masai of southern Kenya and northern Tanzania are less precise, their protein intakes appear to be similar, averaging less than 30-35\% of total calories (cf. Taylor and Ho 1971; Ho et al. 1971).

It is tempting to ascribe the Eskimos' striking ability to flourish on a diet of just meat and fat, with protein intakes approaching $50 \%$ of calories, to a unique genetic capacity not seen in other populations. However, many Euro-American explorers have survived for extended periods in the arctic on similar all-meat diets with no ill effects (cf. Stefansson 1944, 1956). Moreover, eighteenth and nineteenth century fur trappers, explorers, and military personnel throughout the temperate and northern latitudes of North America often subsisted on just pemmican, a mixture of 
dried bison or caribou meat and fat (occasionally, though by no means invariably, with small quantities of fruit added). Based on figures cited by Stefansson (1956; see Speth 1989), about 30-35\% of the energy in a typical pemmican mixture was supplied by protein.

Perhaps the clearest demonstration that non-Eskimos can thrive on an all-meat diet was provided by a medically supervised experiment in which Vilhjalmur Stefansson, a well-known arctic explorer, lived healthily for an entire year (1928-1929) in New York City on just animal flesh and fat. Stefansson's average daily intake of protein was about $25 \%$ of calories; the remaining energy was provided by fat (Stefansson 1956; McClellan and DuBois 1930; McClellan et al. 1930).

These observations indicate that the protein content of all-meat diets can vary over a considerable range, from as low as $25 \%$ or less of total calories, as in the Stefansson experiment, to $30-35 \%$ in pemmican, to a maximum of about $45 \%$ of calories in some traditional Eskimo diets. I am not aware of any all-meat diets (or other "traditional" high-protein diets such as those seen in Ache foragers or East African pastoralists) where the protein contribution regularly exceeds 50\%. Høygaard (1940:56), in fact, documents the concern shown by Greenland Eskimos to maintain their protein intakes below $50 \%$ of calories:

The Angmagssalik Eskimo seem to prefer a diet which nearly covers half the energy requirements by fat and half by protein. Larger quantities of either are only eaten with reluctance. It might be thought that the reason is that the Eskimos, who frequently have far more blubber at their disposal than lean meat, try to save the latter by eating so much fat as possible. But this is not the only factor which lies behind the relatively constant proportion between the two groups of food constituents, as even in time of plenty the proportion remained approximately constant. (In the case of extreme hunger, however, the consumption of fat usually predominates.)

Despite the uncertainty that still surrounds the issue of high protein intakes, in subsequent discussion I will use a value of about $300 \mathrm{~g}$ (roughly $50 \%$ of total per capita daily caloric intake under normal, nonstressful conditions) as the approximate upper limit to the amount of protein that can be consumed safely on a sustained basis. The extent to which this threshold varies among foraging populations because of genetic factors, or is affected by the absolute amounts or relative proportions of fat and carbohydrate in the diet, unfortunately remains unknown.

Of particular interest from a demographic perspective, in pregnant women the safe upper limit to total protein intake may actually be considerably lower than $300 \mathrm{~g}$. While maternal protein intakes must be sufficient to avoid deficiencies, several recent studies suggest that supplementation of maternal diets with protein in excess of about $20 \%$ of total calories (i.e., above about $100-150 \mathrm{~g}$ of protein) may lead to declines 
rather than gains in infant birth weight, and perhaps also to increases in perinatal morbidity and mortality as well as cognitive impairment. Infants who are born prematurely appear to be most vulnerable to very high maternal protein supplements (Rush et al. 1980; Rush 1982, 1986, 1989; Sloan 1985; Kerr-Grieve et al. 1979; Worthington-Roberts and Williams 1989:88). Birth weights also decline when the mother's total calorie intake is restricted (Martorell and Gonzalez-Cossio 1987; National Academy of Sciences 1985; Rush 1989; Winick 1989), but declines appear to be particularly severe when the diet is both low in total energy and high in protein. This is strikingly demonstrated by data from Motherwell, a small community in Scotland, where for 30 years pregnant women were advised to consume a diet consisting of about $1500 \mathrm{kcal}$ and $85 \mathrm{~g}$ of protein (ca. $23 \%$ of total calories). Infant birth weights from Motherwell over this period were on average approximately $400 \mathrm{~g}$ lower than those of infants born in Aberdeen during the same period (Winick 1989:56). Declines in average birth weight of this magnitude are comparable to those seen during wartime famines (see discussion in Rush 1989).

It is important to stress that these observations on the potentially detrimental effects of high maternal protein intakes on infant birth weight, as well as on perinatal morbidity and mortality, are controversial at present. Most studies have been plagued by problems of research design and measurement precision (see Rush 1989), and few have addressed the actual mechanisms by which high maternal protein intakes impact fetal health and development. Nevertheless, if the results of these studies stand up to future investigation, the total protein intake of pregnant women may prove to be an important factor in understanding the food-sharing behavior, food taboos, and reproductive ecology of hunting and gathering populations. This interesting phenomenon clearly deserves more study by nutritionists and medical specialists.

It also raises some very intriguing questions about possible differences by sex in the composition of forager diet that unfortunately cannot be answered at present. If pregnant women ideally should keep their per capita daily protein intake below about $20 \%$ of total calories (i.e., less than roughly $100-150 \mathrm{~g}$ ) in order to protect the health of their fetus, how was this accomplished in traditional northern latitude foraging societies, such as the Eskimos, where protein intakes are often reported to have been much higher? One possibility, of course, is that forager women in these latitudes were not generally successful in restricting their protein intakes to levels below this threshold, with concomitant declines in the health and survivorship of their offspring. Another possibility is that arctic and subarctic foragers possessed a unique set of physiological and metabolic adaptations to very high dietary protein levels. Finally, it is also possible that the traditional diet of women in these groups, particularly 
pregnant women, contained higher proportions of carbohydrates, and perhaps also fat, than did the normal diet of adult men. Unfortunately, most studies of diet in northern latitude foraging societies are very normative; only a few differentiate between the diets of the sexes (see, for example, Bogoras 1904-1909:199; Eidlitz 1969:41-42; Giffen 1930:18), and none to my knowledge describes in any detail the diet of women at different stages in their reproductive career.

Interestingly, one feature of northern latitude diets that is very widespread, if not universal, is the eating of caribou (and reindeer) stomach contents (see, for example, Eidlitz 1969, and references therein). Though often dismissed in ethnographic and ethnohistoric accounts as a minor or incidental food source, caribou stomach contents would certainly have offered an abundant and potentially critical source of already partly digested carbohydrates in habitats where more "orthodox" edible plant foods are normally assumed to have been very scarce or unavailable (see Nickerson et al. 1973; Hunn 1981; and Eidlitz 1969 for general discussions of plant food availability in northern latitudes, and in particular their comments concerning the tendency of reports from these regions to underestimate the dietary importance of carbohydrate resources). Unfortunately, I have yet to find clearcut information on whether women, and most particularly pregnant women, were more likely than men to consume the contents of animal stomachs.

Seaweed or kelp would have been another potentially important source of carbohydrates for women in the arctic (Eidlitz 1969), one which at least in some areas (e.g., Baffin Island) apparently was harvested year-round (even through a hole in the ice in winter; Harriet V. Kuhnlein, personal communication).

In sum, the high protein intakes of arctic and subarctic foragers clearly present an intriguing anomaly, one which underscores the urgent need for more detailed information on the diets of women in these habitats over the course of their reproductively active years.

In discussing the safe upper limit to total protein intake, it is important to emphasize that protein is obtained from plant foods in the diet as well as from meat. Most studies of hunter-gatherer diet tend to ignore or downplay the protein contribution of plants, probably because many vegetable foods do, in fact, have relatively low levels of this macronutrient, and because plant protein generally is inferior in biological value to animal protein (cf. Scrimshaw and Young 1976). Not all plant foods, however, are impoverished in protein. The diet of the Kalahari San (Bushmen or Basarwa) provides an interesting case in point.

According to Lee (1979:271), on average over $16 \%$ of the total per capita daily calorie intake of the !Kung (ca. $2300 \mathrm{kcal}$ ) is provided by protein. As Lee himself notes, this is an unexpectedly high protein intake. 
For comparison, the average American consumes only about $14 \%$ of total energy in the form of protein; and athletes, in the days before carbohydrate loading came into vogue, seldom exceeded 17 or $18 \%$ of calories, and most took in considerably lower amounts (McGilvery 1983:790; Lemon et al. 1984; Shils and Young 1988:1011).

Interestingly, only about $6 \%$ of an adult !Kung's total daily calorie intake comes from protein in meat, while nearly two-thirds comes from protein in plant foods. The protein from mongongo nuts alone accounts for $10 \%$ of total calories. This quantity is roughly sufficient to meet an adult San's minimum daily protein requirement-commonly assumed to be about $10 \%$ of calories-without consuming any meat whatsoever (Adair 1987:120, Table 1; Hegsted 1978; Scrimshaw and Young 1976). While the biological value of the protein from mongongo nuts (and most other plant foods) undoubtedly is inferior to that of animal protein, the San's extremely eclectic plant food inventory (e.g., Lee 1979) very likely compensates for any amino acid shortages or imbalances in their vegetable staples.

Payne (1975) argues that lower protein intakes-on the order of 5\% of total calories-may actually be sufficient to meet minimum daily protein requirements, even in growing 2- to 3-year-old children, provided that their total energy intake is adequate. Hegsted (1978:62) concurs, pointing out that human breast milk, obviously the ideal food for a growing infant in its first 6 months of life, is a "low-protein" food, providing only about 5 to $6 \%$ of the total calories in the form of protein, or ". . . about the level found in rice and less than the protein content of wheat and corn" (see also Brooke 1987:100; Goldman et al. 1974; Plath et al. 1985:407; Shorland 1988:170; but see Pellett and Young 1988 for a contrasting view).

If Payne and Hegsted are correct, the San probably commonly exceed their minimum daily protein requirements, perhaps by a generous margin, on plant foods alone. And for pregnant women, heavy reliance on highprotein plant foods during periods of restricted overall food availability may push their total protein intakes above ca. $20 \%$ of calories, potentially endangering the health of the fetus (Rush et al. 1980; Rush 1982, 1989; see Eaton and Konner 1985; and Konner et al. n.d. for data on average protein levels in a wide spectrum of hunter-gatherer vegetable foods). It is worth noting in this regard that the proportion by weight of protein in mongongo nuts (28.8\%; Wehmeyer et al. 1969), or in Bauhinia beans (31.6\%) consumed by San in the Central Kalahari (Tanaka 1980:55-74; Silberbauer 1981:274), is higher than the average protein content of fresh meat (ca. 21\%; Speth and Spielmann 1983).

If we accept the $300 \mathrm{~g}$ or $50 \%$ threshold suggested above as a rough approximation of the safe upper limit to sustained total daily protein intake, and for the sake of simplicity we ignore the presence of small 
amounts of fat in the meat, the maximum amount of lean meat the San can safely consume on a regular basis, with absolutely no intake of plant protein, would be slightly under $1.4 \mathrm{~kg}$ per capita per day (i.e., $1150 \mathrm{kcal}$ or $288 \mathrm{~g}$ of protein). If we add in the protein from their plant foods, the San can safely take in an additional $40 \%$ of their calories $(920 \mathrm{kcal})$ in the form of animal protein, or about $230 \mathrm{~g}$. This is roughly equivalent to consuming about $1.1 \mathrm{~kg}$ of lean meat. Because of the substantial obligate water loss that accompanies a diet high in animal or plant protein (Alfred E. Harper, personal communication; see also Draper 1977:312), their intake probably will be lower. In fact, the actual per capita daily meat intake of the !Kung is considerably lower, averaging only about $0.23 \mathrm{~kg}$ (Lee 1979:271).

Given these figures, it is interesting to note an observation made by Lee (1982:40):

In late-spring and early-summer [late-dry-season and early-rainy-season] hunting camps the proportion of meat may sharply rise. In one study, the four hunters of a small camp of 12 killed 29 animals in 17 days for a per capita consumption of almost two kilos of meat [ca. $420 \mathrm{~g}$ of protein] per day. These bursts of meat-eating tend to be of short duration, however. . . . (emphasis in original).

This astounding meat intake would provide up to $70 \%$ or more of an individual's total daily calories in the form of protein, a level well in excess of the $300 \mathrm{~g}$ threshold suggested earlier, and well above the normal intakes recorded in the arctic, and therefore very likely deleterious if sustained for more than a brief period. In other words, hungry or not, the San cannot persist on such high protein intakes for extended periods of time without risking serious health consequences. Shortages of water and elevated temperatures at this time of year may significantly increase the adverse effects of a diet high in protein, since the need for a substantial increase in water intake may not elicit an immediate response (A. E. Harper, personal communication). Morever, when protein intakes fluctuate rapidly between low and high levels, a common feature of San procurement patterns at this time of year, the rate at which the body can adapt to the increased amino acid load may by exceeded, again leading to acute adverse effects (Harper 1974a:16). Deficiencies in micronutrients may compound these problems. Of particular note is the fact that San body weights fall to their lowest values at precisely the same time of year (Wilmsen 1978, 1982). Thus, in their attempt to maintain adequate total caloric intakes, it appears that the San are forced to consume excessive amounts of dietary protein, a situation which may pose a serious nutritional problem for them during the late dry season and early rainy season, and most particularly during bad years. As already noted earlier, such extremely high protein intakes at this time of year may be especially detrimental for pregnant women, contributing to depressed infant birth 
weights and increased perinatal morbidity and mortality (Rush et al. 1980; Rush 1982, 1989; Kerr-Grieve et al. 1979). As a consequence, the availability of lipids (and obviously carbohydrates as well) at this time of year, and their equitable distribution within the group, become critically important issues.

\section{LEAN MEAT AND FOOD SHARING}

These observations on the potentially deleterious effects of excessive protein intakes have an important bearing on meat sharing among huntergatherers during seasonal or interannual periods of resource stress, when other sources of calories, most notably carbohydrates, often become scarce or unavailable. As already noted, animals differ in their total fat content and fatty acid chemistry, by species, age, sex, seasonal food intake, reproductive state, disease and parasite load, and body part. It should be clear, therefore, that descriptions of hunter-gatherer meat sharing which merely assert that an "animal was divided into equivalent parts and everybody received an equal share" are inadequate, and project a normative and idealistic image that may be unwarranted (see also Flanagan 1989:248). It is very difficult to divide up an animal in such a way that everyone receives a portion of the carcass with the same total fat content and fatty acid composition. Moreover, parts that are nutritionally valuable at one time of year may be fat-depleted and of limited use at another. Thus, in order to evaluate the nutritional equity of an act of sharing, at a minimum we need to know (1) who gets each part of the carcass; (2) the fat content of each part; and (3) the physiological condition of the people who receive fat-rich parts and of those who get lean parts.

Unfortunately, the ethnographic literature on food sharing rarely treats these issues in sufficient detail. Most ethnographic reports merely note that meat was shared, a few describe the specific anatomical units that were shared (occasionally providing diagrams with native terms for each part), and only a handful actually document the kinship relationships among participants. However, almost none describes the physiological condition of the animals being shared or of the recipients of the shared parts. Moreover, most ethnographic reports provide no insights into seasonal or interannual variability that might occur in the pattern of sharing under differing degrees of resource stress. In fairness to ethnographers, these are obviously very difficult and time-consuming data to collect, but they are essential if we are to understand the variability that characterizes hunter-gatherer adaptations in different ecological settings.

Despite the present paucity of information, there are a few intriguing cases in the hunter-gatherer literature that underscore the potential nutritional significance of being denied access to fat or fatty meat. Many of 
these cases involve differential access by women, and therefore may be significant in understanding the low fertility and high infant mortality seen in many foraging populations (see, for example, Bolton 1972; Howell 1979, 1986; Huss-Ashmore 1980; Loudon 1987; Rosenberg 1980; Spielmann 1988, 1989; Wilmsen 1986; but see Bongaarts 1980 and Campbell and Wood 1988:44 for contrasting views). For example, observations of a traditionally oriented Australian Aboriginal community in northeast Arnhem Land by White (1985) suggest that the health status of adult women in this group was decidedly poorer than that of males. Similar observations were made by Hetzel (1978) among groups in Central Australia. The antiquity of this pattern in parts of Australia is documented by Webb's (1988) longitudinal study of stress indicators and paleopathologies in prehistoric Aboriginal skeletal remains. While the poorer health status of women seen in these groups probably to some extent reflects historic and recent changes in diet brought about by contact with Europeans, as well as the stresses of child-bearing and heavy workloads (cf. Bentley 1985), part nevertheless appears to be directly attributable to traditional inequalities in access to food (Cowlishaw 1981; Dugdale and Lovell 1981; Hetzel 1978:41; Lumholtz 1889:161, cited in Harris 1978:127; White 1985). This is clearly the case, for instance, in White's (1985) group in northeast Arnhem Land, where women, regardless of age or reproductive status, routinely received smaller shares of meat than did males and often were not permitted to eat animal fat. White's observations are succinctly echoed by Hetzel, who states that the "order of precedence of food distribution-old men, hunting men, children, dogs and womensuggest[s] females are the most likely to develop malnutrition. . . ." (1978:41).

Moreover, taboos among many Aboriginal groups (e.g., Murngin, Walbiri, and Aranda) prohibit women at critical times in their reproductive cycle (i.e., at puberty or when they are pregnant or nursing) from consuming meat or fat (Spielmann 1988, 1989; see also Kaberry 1973:78-79n, 94, 100, 169n; White 1985). As suggested by Spielmann (1988, 1989), by restricting caloric intakes, these practices during periods of stress may be of considerable demographic significance, perhaps affecting both the fertility of the women and the birth weights and mortality patterns of their offspring (see also Ellison et al. 1986, 1989; Lager and Ellison 1987; Lechtig et al. 1978; Wray 1978).

It is worth digressing here for a moment, however, to stress that seemingly inequitable food-sharing practices and food taboos, which effectively block pregnant women from access to many or all animal products, may have significant beneficial as well as detrimental effects, and at present it is impossible to assess which effects are greater. Moreover, the actual costs and benefits may change at each stage during the growth and 
development of the fetus. For example, as discussed earlier, studies by Rush (1982, 1986, 1989), Sloan (1985), and others (e.g., Kerr-Grieve et al. 1979) suggest that high-protein maternal food supplements, in which protein provides more than about $20 \%$ of total calories, may lead to depressed infant birth weights and increased perinatal morbidity and mortality. Thus, sharing practices and taboos which keep the total protein component of the maternal diet below this level, but sufficient to avoid protein deficiencies, may actually enhance the health and survivorship of the offspring, provided that the mother's total energy intake is not significantly compromised in the process.

Food taboos and inequitable meat-sharing practices may have other important positive tradeoffs for pregnant women as well. For example, forager women are commonly denied access to the liver, kidneys, and other internal organs of animals. Liver can be an extremely potent source of vitamin A, a nutrient well known for its teratogenic or toxic effects on the fetus when consumed during pregnancy in excessive doses (e.g., spontaneous abortion, birth defects, permanent learning disabilities; see Olson 1988:302; Lansdown 1983; see also Wilson 1977a for a general discussion of teratology). The liver, kidneys, brain, blood, and other animal tissues may also contain teratogenic or embryocidal concentrations of heavy metals (Reilly 1980; Spallholz et al. 1981; Underwood 1973). Those that are known, or suspected, to be teratogenic or embryocidal include arsenic, beryllium, cadmium, copper, lead, lithium, possibly manganese, mercury, selenium, and possibly zinc (Luckey and Venugopal 1977; Wilson 1977b:369).

Heavy metals occur naturally in bedrock and soil and are released into the environment by chemical weathering and leaching, volcanism, wind erosion and transport, the actions of plants and microorganisms, and a variety of other processes (Connell and Miller 1984:288-332). These metals form a wide array of inorganic and organic compounds which may become concentrated in water and vegetation, and if ingested or absorbed by animals may become further concentrated in their blood, brain, liver, kidneys, bones, and adipose tissue (Ferm 1972; Hayes 1975; Lansdown 1983; Luckey and Venugopal 1977; Reilly 1980; Street and Sharma 1977). While many of these compounds are metabolized or degraded and excreted fairly rapidly, others, particularly those which are highly lipophilic (lipid-soluble), may pass readily into the animal's brain or accumulate in adipose tissue (Barthalmus 1980:109; Miller 1984:12). Through a process known as biomagnification, many of these toxic compounds may become increasingly concentrated as one moves up the food chain, with the highest levels often occurring in predators, both aquatic and terrestrial (Moriarity 1983:135-136; Connell and Miller 1984:309-312, 358; Barthalmus 1980; Leidy 1980). Fish also absorb toxic substances directly from the 
water, and many filter-feeders (e.g., shellfish and crustaceans) may concentrate unusually high levels of toxic heavy metals, especially arsenic, mercury, and zinc, in their tissues (Dickerson 1980:3; Reilly 1980:110, 126). Thus, potentially teratogenic concentrations of these substances are particularly likely to be encountered in marine species.

During periods of resource stress, when animals are forced to mobilize their body-fat reserves, concentrations of many lipid-soluble compounds may be elevated even further in the remaining adipose tissue, as well as in the brain, blood, and internal organs (e.g., Hayes 1975:165; Street and Sharma 1977:490). Moreover, mesenteric fat may accumulate greater quantities of these toxic substances than does cutaneous fat. The differential storage potential of these and other tissues appears to depend in large part on differences in the rate of blood flow (Street and Sharma 1977:490). And since cutaneous fat deposits tend to be mobilized in a stressed animal before mesenteric ones, the lipids that are most likely to be available to foragers during a period of prolonged or severe resource stress may derive primarily from the potentially more toxic mesenteric deposits. Thus, the risk to a pregnant forager woman of consuming meat or animal fat that is laden with toxic levels of teratogenic substances may be substantially greater during seasonal or interannual stress periods, when plant foods are in short supply and the women are forced to obtain a greater proportion of their total calories from fat-depleted animal tissues.

Interestingly, food cravings and food aversions, as well as the nausea and vomiting of pregnancy sickness (i.e., "morning sickness"), may play an important role in reducing the likelihood that a pregnant woman will ingest potentially teratogenic or embryocidal substances (Profet n.d.). These cravings, aversions, and symptoms of pregnancy sickness are most prominent during the first trimester, the period of embryonic organogenesis when the developing fetus is especially susceptible to teratogens. A tremendous diversity of food cravings and aversions have been documented in pregnant women, making it extremely difficult to draw reliable generalizations. Nevertheless, most studies concur in showing strong preferences for sweet, carbohydrate-rich foods, such as fruits and candies, and widespread aversions for high-protein foods, particularly meat, poultry, and often fish (Dickens and Trethowan 1971; Hook 1978; Profet n.d.; Tierson et al. 1985). While it remains unclear whether the aversion for meat stems from the potential presence of teratogens in animal tissues or instead from toxic properties of the protein itself when consumed in large quantities, what is of particular interest to us here is the widespread occurrence of this food aversion among pregnant women, despite the increased protein needs of both mother and developing fetus.

It must be stressed that many of the substances found in animal tissues 
at levels high enough to be embryocidal or teratogenic can be traced to comparatively recent industrial and agricultural practices which introduce large quantities of man-made chemicals into the environment. Foragers in the past would certainly not have faced the dangers of chemical pollution that modern populations everywhere must now confront. Moreover, naturally occurring heavy metal concentrations prior to the Industrial Revolution are likely to have been highly localized, their distribution depending on the composition of local bedrock and soil as well as on particular sets of environmental and climatic conditions (e.g., high evaporation rates that concentrate heavy metal compounds in drinking water). Nevertheless, high levels of potentially toxic heavy metal compounds (e.g., mercury) almost certainly did at times occur in the past, particularly in marine contexts, as has been demonstrated repeatedly by the analysis of tissues from museum fish specimens that were collected 50-100 years ago (e.g., World Health Organization 1972:16; Reilly 1980:111-112). Thus, at least some of the seemingly peculiar and inequitable food taboos and foodsharing practices observed among contemporary foraging populations may prove to have a sound underlying basis in nutrition. However, in most cases their nutritional role remains to be demonstrated. And, more importantly, we have yet to unravel the precise mechanisms by which foragers would have been able to key into the often subtle relationships between diet and pregnancy outcome. One thing is abundantly clear from this discussion, however; food taboos and food-sharing practices must be examined much more closely in the future, not just for their symbolic content, but also for their nutritional and demographic significance.

Returning now to our discussion of inequitable meat-sharing practices among contemporary foragers, the status of !Kung San women, and their overall health and nutritional condition, seem to be better than among the particular Australian Aboriginal groups discussed by White and Hetzel (Begler 1978; Nancy Howell, personal communication; Howell 1979, 1986; Lee 1982; Truswell 1977). Perhaps even their birth rates are somewhat higher (Cowlishaw 1981:38). Nevertheless, there is growing evidence that the !Kung and other Kalahari foragers experience repeated seasonal and interannual stress. For example, according to Wilmsen $(1978,1982)$, who weighed over 80 men and women at seven intervals during the course of a year, the !Kung lose up to $6 \%$ of their body weight by the end of the dry season; other investigators have documented parallel changes in skinfold thickness (Truswell and Hansen 1976; Truswell 1977).

Numerous other lines of evidence also point to recurrent food stress among the San (cf. Gaulin and Konner 1977:69; Wiessner 1977, 1981; Harpending and Wandsnider 1982). For example, Howell (1986) refers to the !Kung as chronically undernourished, a rather dramatic shift in per- 
spective from the view presented two decades earlier by Richard Lee and Marshall Sahlins in Man the Hunter (Lee and DeVore 1968); Bentley (1985) and Blurton Jones and Sibley (1978) have emphasized the San's high and potentially stressful workloads, as well as the problems they face in maintaining thermal balance in their desert environment; Metz et al. (1971) note that the !Kung suffer from a high incidence of hookworm and other parasitic competitors for nutrients; Hitchcock (1986) and Wilmsen and Durham (1988) note that mongongo nut trees do not provide a perpetual bonanza of food for the !Kung, but, like many other nut-bearing trees, periodically fail; Konner and Shostak (1987) suggest that the high suckling frequency of !Kung infants, one of the key factors responsible for maintaining low fertility levels among the San, may in part reflect inadequate milk production by lactating mothers (see also Lunn 1988); Hausman and Wilmsen (1985:57) present evidence of significant undernutrition and retarded growth in San girls; Truswell and Hansen (1976:190), Tobias (1962), and Stini (1981) attribute the small size of the !Kung, at least in part, to chronic caloric insufficiency; and, as already noted, the consumption by the !Kung of up to $2 \mathrm{~kg}$ of lean meat per person per day at the height of the dry season is almost certainly a response to resource stress (Lee 1982:40). Thus, while the !Kung and other Kalahari foragers may not be hovering perpetually on the brink of starvation, they certainly are not the "original affluent society" that Sahlins (1968) once led us to believe they were.

Given these observations on resource stress among the San, the availability of animal fat, and its distribution among members of the group, become issues of key concern. Animal fat is an extremely scarce commodity in the Kalahari at all times of year (e.g., Ledger 1968; Sinclair 1974, 1975), and it is highly prized (e.g., Marshall 1976; Silberbauer 1981; Yellen 1977:293). In prime condition, the ungulates hunted by the San, with the possible exception of the eland (Silberbauer 1981:275), may have as little body fat as most northern and temperate latitude large mammals have when they are severely stressed; and, during the height of the dry season, many of them may be largely depleted of their limited body fat reserves (Speth 1987a). To retrieve this scarce resource, the San carefully extract the marrow from the long bones, and systematically boil the broken up limb bones and axial elements to obtain the grease (Yellen 1977). Unfortunately, despite the many published discussions of San meat sharing (e.g., Lee 1979), no one has yet systematically considered how the fat itself is distributed. Nevertheless, there are suggestions that fat is not always shared equitably, again particularly with women. For example, Marshall notes that men may consume most or all of the limited yield of marrow fat (and fatty organs of the head such as the brain and tongue) while snacking at a kill, bringing primarily lean meat back to camp to share: 
when the kill is made, the hunters have the prerogative of eating the liver on the spot and may eat more of the meat until their hunger is satisfied. If they are far from the band, they may eat the parts that are especially perishable or most awkward to carry, like the head, and they sometimes eat the cherished marrow. (1976:296)

Yellen, in a detailed discussion of !Kung butchering practices, makes a similar observation:

. . special portions of the animal, such as the cannon bones and the liver, are set aside for cooking and consumption at the kill site by the hunters. In this latter regard a consistent pattern is observed: the marrow in the cannon bones and the liver belong to and are usually eaten by the hunters at the kill. (1977:280)

The cannon bones, or metapodials, are among the most important marrow bones in the carcass of an ungulate. While they contain only moderate amounts of marrow, the lipids in the marrow of these bones are considered especially good tasting cross-culturally and, most importantly, may be among the last reserves to be depleted in an animal suffering from resource stress (Binford 1978; Speth 1983).

Thus, while !Kung patterns of sharing and food taboos clearly are not as blatantly inequitable as they appear to be among at least some groups of Australian Aborigines, animal fat nevertheless may often go largely to men. Again, as among Australian foragers, women's more limited access to animal fat may have important nutritional consequences, particularly when periods of seasonal or interannual environmental stress coincide with high reproductive demands.

Similar patterns of discrimination against women have been reported among the Hadza, foragers inhabiting the mixed savanna woodlands along the eastern side of Lake Eyasi in Tanzania (Bunn et al. 1988:442; Barnard and Woodburn 1988:17-18; Barnicott et al. 1972:112).

\begin{abstract}
It is difficult to establish beyond a reasonable doubt what the principal factors were in determining why the Hadza men handled the last three impala carcasses in the described manner. Because additional carriers were available nearby but were not sought by the Hadza men with the carcasses, it does not seem likely that an insufficient number of available carriers led to the documented behavior. It seems more likely that the principal determining factors for these individuals fall under the heading of "other plans" and may perhaps relate to their personal inclinations about sharing the carcasses with the larger camp population. Had their principal goal been to maximize sharing with the camp population at large, then they would probably have enlisted additional carriers or they would have selectively transported the parts that provide the best nutritional yield. That they chose not to do this, and instead ate the high yield limb parts by themselves, suggests that a deliberate avoidance of haring the best carcass parts was a principal factor in those examples. (Bunn et al. 1988:442)
\end{abstract}

O'Connell et al. (1988) observed similar behavior among other Hadza groups, but feels that the behavior serves primarily as a means of reducing 
transport costs. Bunn et al. (1988:443) concur that transport costs may be a factor in the behavior, but also emphasize the nutritional consequences:

Processing and discarding the limb elements at butchery sites certainly reduces transport costs; it also guarantees that the Hadza men at the carcass have preferential access to the highly nutritious marrow of limb bones.

Views similar to those of Bunn et al. are echoed by Barnard and Woodburn (1988:17-18) and Barnicott et al. (1972:112).

Inequitable access to meat and fat is also apparent among the Pygmies. For example, Hewlett et al. (1982) note that Aka males spend more time than women away from camp on long trips, and as a consequence have greater access to meat (and presumably fat). Walker and Hewlett (n.d.) and Hewlett (1988) also note that Aka and Mbuti males have fewer caries and other forms of dental disease than do females, and they attribute at least part of the difference to diet. In addition, Ichikawa (1983) notes that only certain Mbuti men get the heads of larger mammalian prey, clearly depriving women of a very important fat source-the brain. Bahuchet (n.d.) makes a similar observation for the Aka. These and other factors suggest that Aka and Mbuti women have a diet distinctly inferior to that of men.

Interestingly, in a recent study of kangaroo body part transport among the Alyawara of Central Australia, O'Connell and Marshall (1989) specifically examined the issue of whether fat-rich carcass parts were differentially consumed by hunters at kill sites, or were instead brought back to camp along with the rest of the carcass. Their results indicate that at least in this case hunters did not monopolize the best parts directly at the kills. This interesting study underscores the considerable variability that appears to characterize forager behavior at kill sites, and points to the need for additional quantitative studies of the fate of animal tissues (and other foods) from initial procurement to distribution, sharing, and consumption.

In addition to women's differential access to animal fat, in many foraging societies, as a consequence of inequitable sharing practices and food taboos, there is another factor that may prove to be demographically significant. According to Mildred Dickemann (personal communication), there are many small-scale agricultural societies that intentionally fatten girls at puberty on calorically rich diets. In admittedly cursory surveys of the hunter-gatherer literature, Dickemann and I have encountered very few comparable practices among foragers (the Ache appear to be a notable exception; Kim Hill, personal communication). Quite the contrary, heavy workloads, inequitable sharing practices, and an array of food taboos all seem geared toward keeping women in many foraging groups undernourished (see also Rosenberg 1980; Hayden et al. 1986). The underlying cause for this striking pattern remains unclear, but more likely 
stems from adult male efforts to enhance their own status and nutritional well-being than from deeply embedded societal strategies for regulating the fertility of women (Kim Hill, personal communication).

I should point out that nutritional inequities arising from differential food-sharing patterns or taboos may be of little or no significance for much of the year. Since women do most of the gathering, they generally have direct access to sufficient quantities of vegetable oils and carbohydrates, as well as fat from insects and small vertebrates, to compensate for inequities that may arise from the sharing of larger mammals. The critical issue, however, is what happens to the nutritional intake of women, especially pregnant or nursing women, during the annual low point in resources (i.e., late winter-spring or height-of-dry-season), or during particularly bad years. These are the critical adaptive "bottlenecks," to use Wiens' (1977) terminology, when inequitable foodsharing practices and taboos are most likely to play a significant role.

Another brief digression is in order here. Many foragers (e.g., !Kung, Pygmies, and Australian Aborigines), though by no means all, have strikingly low fertility levels and high rates of infant mortality, phenomena that have attracted a great deal of attention by anthropologists and demographers (see Hill and Hurtado 1989). My position throughout this discussion has been that a forager woman's unequal access to meat or fat, particularly during periods of reduced total calorie intake, may play a role in depressing her fertility, and may also contribute to high rates of infant mortality by compromising the health and survivorship of the fetus and newborn infant. In other words, food taboos and uneven food-sharing practices may exert a negative influence on the total reproductive output of foraging women in groups where these inequities are particularly marked. That seasonal or interannual weight loss can significantly lower fertility is clearly shown by recent work in the Ituri Forest and elsewhere using salivary progesterone levels. These studies show that even moderate declines in body weight may have a significant negative impact on a woman's ovulatory frequency, mean luteal progesterone levels, and luteal phase length (Lager and Ellison 1987; Ellison et al. 1986, 1989).

An interesting related issue, but one which is beyond the scope of the present paper, is whether a reduction in reproductive output among forager women, stemming from inequitable food-sharing practices and food taboos, or from other factors, reflects lowered reproductive fitness or instead a complex adaptive strategy that actually optimizes a woman's lifetime reproductive output, particularly in harsh or "marginal" environments. Unfortunately, much more research must be done among the world's remaining foragers before we can begin to adequately address this highly complex but important issue (for interesting recent discussions concerning the reproductive fitness of one group of foragers-the 
!Kung-see Blurton Jones 1986; Blurton Jones and Sibley 1978; and Pennington and Harpending 1988).

Up to this point, I have focused on women's restricted access, relative to that of men, to fat or fatty meat. However, the "snacking" behavior of San and Hadza hunters directly at the site of a kill, a behavior pattern widely noted among foraging societies, suggests that more active or successful hunters in the group sometimes may have greater access than do other men to the nutritionally most valuable parts of an animal carcass (but see O'Connell and Marshall 1989 for an interesting counter-example). This is strikingly seen, for example, among the Aka Pygmies, where higher status males have access to more meat and fat than other men, and are on average $3 \mathrm{~cm}$ taller and have fewer caries (Hewlett 1988:271).

It is often stated that good hunters are compelled to share their catch with others, so that in the long-run less skilled hunters and their families should fare about as well as the more successful ones. This view is clearly expressed, for example, by Nancy Howell, who states that

sharing is such a pervasive feature of !Kung life that there is not much caloric advantage in being married to, or being the child of, a good hunter (or, for a man, being a good hunter rather than a poor or lazy one), since what matters is simply that there should be a good hunter in the group. (1986:164)

However, with the notable exception of Kaplan and Hill's (1985b) detailed study of food sharing among the Ache of eastern Paraguay, anthropologists have seldom demonstrated this systematically with quantitative data on the actual meat weights received by different members of the band. More importantly, few studies have documented the fat content and fatty acid composition of the shared portions and compared these to the parts that were eaten by hunters directly at the kill. As I have already noted, during severe seasonal or interannual periods of resource stress, in which caloric intakes drop markedly and weight loss becomes significant, less successful hunters and their families who receive fat-poor parts, regardless of the weight of the share, may be getting meat that is nutritionally inferior.

Though presently limited, there are tantalizing data which support these suggestions. Siskind (1973), for example, cogently argued more than a decade ago that better or more active hunters were reproductively more successful. More recently, Kaplan and Hill (1985a; see also Hill et al. 1987), working among the Ache, have come to similar conclusions, but with far more quantitative, and hence more compelling, data. According to these authors,

this increase in fitness [of more successful hunters] is due to both increased survivorship of offspring and increased access to extramarital affairs through which illegitimate offspring are produced. (1985a:132) 
Comparable observations are reported by Bailey (1988) for Efe Pygmy hunters in Zaire and by Hewlett (1988) for Aka Pygmy hunters in the Central African Republic.

Interestingly, the more stylized and traditional the pattern of butchering and subsequent meat distribution among the participants (cf. Binford 1984; Gould and Watson 1982), the more likely it is that certain individuals, or groups of individuals, consistently will receive nutritionally less valuable cuts of meat (see also Henry 1951 for an interesting discussion of long-term asymmetries in food sharing). In other words, if custom dictates, for example, that certain group members always get the neck or front end of an animal, and the forequarters in this particular species are more susceptible to fat depletion than are the hindquarters, then during critical times of environmental or physiological stress, these individuals will be blessed with carcass parts of inferior nutritional worth. Ironically, what has been looked upon by most anthropologists as a system to guarantee equity among group members in access to meat, may in fact at times act to create or exacerbate underlying nutritional inequities that could become critically important during seasonal or interannual periods of stress.

Finally, there is another potential source of nutritional inequity that may arise between hunters. In foraging societies where hunters not only are required by custom to share the meat they procure with other members of the group, but are themselves precluded from consuming any significant portion of it, single hunters may end up faring consistently worse in the amount of meat they receive than do married hunters with dependents (Kaplan et al. 1990:127). Over the long run, these differentials between hunters might be expected to even out were it not for the fact that a significant number of males in many foraging societies remain bachelors throughout their lifetime (e.g., Bailey 1988).

\section{CONCLUSIONS}

In most discussions of sharing, anthropologists have focused primarily on the act of sharing as a social phenomenon. From this perspective, meat sharing appears to be an equitable way of redistributing a scarce and highly valued resource among all (adult) members of the society. By effectively leveling differences in hunting returns that inevitably arise because some hunters are more active or successful than others, meat sharing epitomizes the egalitarian essence of foraging societies. However, when we look more closely at the underlying nutritional worth of the meat that is shared, the potential for serious inequities becomes apparent. Women are the most obvious target of these inequities. They may receive nutritionally inferior portions of the kill, and may be prevented by taboos from eating meat or animal fat at precisely the times in their reproductive 
cycle when this nutrient might benefit them most. Combined with the heavy workloads typically endured by forager women (Bentley 1985), these inequitable sharing practices and food taboos may have significant negative reproductive consequences, particularly during periods of resource stress. However, there may also be positive benefits to pregnant women of these seemingly inequitable practices, specifically by keeping their total protein intake below about $20 \%$ of calories, and perhaps by reducing their exposure to potentially teratogenic substances that may be present in animal tissues. The relative tradeoffs between the positive and negative effects of these taboos and food-sharing practices remain to be explored.

Inequities in meat sharing do not appear to be restricted just to females. More active or successful hunters may have greater access to fat at kill sites, and highly stylized or traditional patterns of butchering and sharing may assure that certain hunters or their families consistently obtain superior quality (fatty) meat. Again, such inequities may become critical during times of food shortage.

Our tendency to focus on the social aspects of food sharing may obscure significant underlying inequalities in access to critical nutrients. Moreover, the very fact that we define foraging or band societies as "egalitarian" may exacerbate the problem, because the term itself implies that transactions involving life-sustaining resources will be equitable, at least among members of the same age cohort and sex. In other words, we are not inclined to look for such inequities in foraging societies, because by definition they should not exist (see Fried 1967 and Service 1971 for classic discussions of egalitarian societies). This problem is compounded by the fact that the foragers themselves may actively express an ethic of "egalitarianism" while at the same time participating in food-sharing and taboo practices that may give rise to significant nutritional inequalities (e.g., Flanagan 1989). Anthropologists sometimes go to rather extreme lengths to "explain away" obvious inequities because they conflict with our deeply entrenched views of egalitarianism in band societies. This is strikingly seen, for example, in a recent statement by Barnard and Woodburn (1988:18) concerning the distribution of certain preferred cuts of meat among the Hadza:

So here we have, within an immediate-return system in which equal access to wild food and other resources and egalitarian sharing of the produce when it is brought into camp are given much emphasis, a quite different and elaborately sanctioned rule which emphasizes . . . the privilege of the initiated men of the camp to consume this special meat jointly. Yet there is a paradox here: the limited sharing of the meat by the initiated men in a special religious context in a sense authorizes and legitimizes the general emphasis on secular sharing of the meat of large game animals. The rules of God's meat require that it be brought back to camp from the kill site and they provide a framework for bringing back the rest of the meat, and putting it at people's disposal. 
In this discussion, $I$ in no way mean to imply that inequitable sharing patterns and discriminatory food taboos are monolithic features of all foraging societies that invariably divide band members into "haves" and "have nots." In fact, what is striking about foragers is the very diversity and complexity of these practices, and this is nowhere more evident than in women's access to animal flesh and fat.

For example, if one were to array foragers along a continuum in terms of the degree of inequity in their sharing practices, the Australian Aboriginal groups described by White (1985) and Hetzel (1978) would fall near one extreme. Their sharing practices (as well as their food taboos) blatantly prevent women from eating animal fat most of their lives.

The Kalahari San, Hadza, and Aka Pygmies would lie more toward the middle of this continuum. Among these foragers, the differential access to animal fat enjoyed by men is far more subtle than in the Australian examples, being largely an indirect consequence of the division of labor; men do the hunting and therefore have greater access to fatty parts at the kill, especially when the animal is too large to be transported back to camp or when the kill is made far from home. Such differential access may be of little nutritional consequence most of the year, but may become significant during the late dry season, or at least during the dry season of particularly bad years.

At the other end of the sharing continuum are the Penan Gang of Sarawak (Borneo) and the Ache of Paraguay. These foragers carefully divide up the fat from each kill so that adult women are assured of getting equitable portions (J. Peter Brosius, personal communication; Kim Hill, personal communication).

However, if we also look at food taboos, the situation becomes more complex and multi-dimensional. In some foraging groups, there are few or no important food taboos, or the taboos are in effect so briefly that they are nutritionally inconsequential. In other cases, otherwise equitable sharing patterns are counteracted by food taboos, which are either in force over long periods of time, or take effect at critical times in the reproductive life of a woman (i.e., at puberty or when she is pregnant or nursing). And in the most extreme cases, as in some groups in Australia, both sharing practices and food taboos reinforce each other to create potentially serious long-term nutritional shortfalls.

The Penan Gang provide an interesting example of the complex interplay between sharing practices and food taboos. Thus, while Penan take great care to share animal fat among adults in an equitable manner, regardless of sex, their food taboos create a far less equitable situation. In particular, lactating women are not allowed to eat animal fat, effectively blocking them (unless perhaps the taboos can be violated without serious consequences) from access to a key resource throughout a major portion of their reproductive life (J. Peter Brosius, personal communication). 
This complex, multi-dimensional array of food-sharing practices and food taboos has received surprisingly little attention from anthropologists. It should be clear from this discussion, however, that inequities in these practices may be of considerable nutritional importance to forager women, and perhaps also to forager men, and that we must explicitly identify and address the cross-cultural variability in these practices, and their ultimate demographic consequences, if we are to achieve a satisfactory understanding of hunter-gatherer adaptations.

It may be useful to digress again for a moment and briefly point out some of the critical data that are needed. As noted earlier, we obviously need systematic and quantitative information from a wide range of groups across a spectrum of ecological settings on what anatomical parts are shared, with whom, and in what quantities. But we also need to know more about the age, sex, reproductive state, and physiological condition of the animals that are being distributed. For age, sex, and reproductive state, the hunters themselves are probably excellent informants. The physiological condition of an animal, however, while certainly recognized by the hunters, may require somewhat more careful investigation. Wildlife specialists, who are concerned with managing viable populations of large game animals, have developed a variety of relatively straightforward methods for in-the-field assessment of condition. One of the most widely used is the kidney-fat index (KFI), the ratio between the weight of fat surrounding the kidney to the weight of the kidney itself (see Kirkpatrick 1980:108-109). Another approach, often used in conjunction with the KFI, is an assessment of the fat content of the marrow in the femur (Kirkpatrick 1980:106-107), which can be readily determined in the field on the basis of the marrow's color and consistency. While many other indices have been developed, these two together provide an efficient and reliable measure of an animal's physiological condition. Obviously, before an ethnographer attempts to conduct these assessments in the field, he or she should consult with an appropriate wildlife specialist.

It would also be extremely useful to have information on the physiological condition and reproductive state of the forager women themselves. Obviously, these kind of highly personal data are much more difficult to obtain than data on the condition of the animals. Nevertheless, detailed demographic studies of foragers are becoming increasingly common (e.g., Hill and Hurtado 1989), and these are providing critical information on female reproductive histories. All that is now needed is to expand these investigations slightly to document the reproductive state of women at the time they participate in specific food-sharing events. In addition, in order to monitor the pattern of resource stress in women, we also need information on their body weights and skinfold thicknesses, measured where possible at regular time intervals. Again, the ethnographer should consult with an appropriate physician or biological anthropologist for advice con- 
cerning the most effective techniques for obtaining these measurements in the field.

And last but not least, the role of food taboos also needs to be investigated far more systematically. Most ethnographies to date have treated taboos largely in normative terms, and have focused more on their symbolic aspects than on their nutritional impact. While in no way downplaying the importance of the symbolic aspects, we need to know precisely which foods are tabood, to which women, for how long, at what time of year, at what point in a woman's reproductive career, the degree to which the taboos can be violated or bypassed as resource conditions become more stressful, and the nutritional impact of the tabood items on both mother and offspring.

Finally, let me close the discussion by raising two somewhat more general issues: the first concerns the importance of sharing beyond the narrow confines of food; the other concerns the concept of egalitarianism as it is commonly applied by anthropologists to foraging societies. Anthropologists often focus almost exclusively on the sharing of food, and especially the sharing of meat from large animals, in models for the origins of band society (e.g., Isaac 1978); and, as a consequence, underemphasize or ignore entirely the fact that foragers actually share a much broader spectrum of social, political, economic, and even sexual rights and privileges. Food and other material items, in fact, form only a small component within this much larger array of reciprocal exchanges and interactions.

Interestingly, this overly narrow, and perhaps misleading, focus on food sharing has been called into question, not by ethnographers or archaeologists concerned with hunter-gatherers, but by primatologists working with chimpanzees and baboons (e.g., de Waal 1982, 1989b; Smuts 1985). Recent primate studies clearly demonstrate that sharing is a complex phenomenon involving much more than food. Both chimpanzees and baboons, at any given point in time, are involved in a wide array of social, political, economic, and reproductive interactions with other members of their social group. Recognition of the importance of these interaction patterns has led Smuts (1985) to question current hominid origin models that assign primacy to the sharing of food:

Most authors considering the emergence of uniquely human male-female relationships place great emphasis on the division of labor and the resulting need for economic exchange between the sexes. . . . According to most scenarios, male and female hominids exhibited relatively undifferentiated social relationships until the division of labor and the food sharing that it generated brought the sexes together into practical, economic arrangements that benefited both men and women. (1985:259)

The nonhuman primate data suggest that this idea ought to be questioned. Monkeys and apes show highly differentiated, long-term relationships between males and 
females in the absence of any economic exchange. These relationships are based, instead, on social reciprocity. . . . It seems likely that hominid males offered females important social benefits long before they were capable of big game hunting. (1985:259-260)

If this hypothesis is correct, then the economic exchange engendered by a division of labor probably developed within the context of male-female relationships that had already existed for a very long time. The usual assumption is that close bonds between the sexes arose because of the need for food-sharing. It seems more likely that it was possible for male-female food-sharing to develop because females and males had already evolved the capacity for close bonds that allowed them to successfully negotiate reciprocal exchange. (1985:260)

Increasingly sophisticated primate studies also point to the potentially misleading nature of the label "egalitarian" when applied to foraging societies. Among baboons and chimpanzees, some of the interactions between individuals are balanced and reciprocal, while others are decidely asymmetrical, favoring one individual over another. The degree to which these interactions remain reciprocally balanced or asymmetrical depends on a variety of factors, including the specific context of the interactions, the past history of exchanges, and the immediate and longerterm needs and objectives of the participants (de Waal 1982, 1989a; Smuts 1985).

Of greater importance for our purposes here, however, is the fact that some of these unbalanced or asymmetrical relationships between individuals, which often convey significant social, political, economic, or reproductive costs and payoffs for those involved, remain that way throughout the lifetime of the participants, and may be passed on to their offspring. In other words, these are relationships that anthropologists would consider "inegalitarian" (e.g., Fried 1967; Begler 1978). Patterns of interaction among human foragers are certainly equally complex and multidimensional, with numerous inegalitarian components not only present but persisting across generations. Subsuming this complex array of interaction patterns under the single term-"egalitarian"-probably obscures the very organizational and behavioral variability and complexity that we seek to identify and explain.

\section{ACKNOWLEDGMENTS}

This paper was presented in a symposium entitled "Coping with Seasonal Constraints" at the 86th Annual Meeting of the American Anthropological Association, Chicago, Illinois, Nov. 22, 1987. An earlier version was presented at the 19th Annual Chacmool Conference, "Diet and Subsistence: Current Archaeological Perspectives," Calgary, Alberta, Canada, Nov. 7-9, 1986 (Speth 1988). I am grateful to Serge Bahuchet, Barrett Brenton, W. F. Buchanan, J. Peter Brosius, Kristen Hawkes, Michelle Hegmon, Kim Hill, Frank Hole, Nancy Howell, Michael Jochim, Robert Kelly, Nobuhiro Kishigami, Katherine Moore, 
James O'Connell, John Parkington, Katherine Spielmann, and Bruce Winterhalder for their many helpful comments and suggestions in the preparation and many revisions of the manuscript. Alfred E. Harper and George F. Cahill, Jr., very generously commented at length on the protein arguments and offered important suggestions for bringing them more in line with current thinking in biochemistry and nutrition. David Rush brought to my attention the important literature on maternal diet and infant birth weight, and Sue O'Shea introduced me to the interesting field of teratology. The arguments in this paper have also benefitted from numerous discussions over the years with Robert $\mathrm{E}$. Whallon about hunter-gatherer adaptations, evolutionary ecology, and the importance of adaptive "bottlenecks." I also thank Dieter Noli and Graham Avery for providing me with a copy of their paper "Protein Poisoning and Coastal Subsistence" prior to its publication in 1988; this paper first brought to my attention the work by Cheremin (1985). Serge Shishkoff of the Department of Slavic Languages at the University of Michigan translated the Cheremin article. Finally, I acknowledge the support of the School of American Research in Santa Fe, New Mexico, where I substantially revised the manuscript.

\section{REFERENCES CITED}

Adair, Linda $\mathbf{S}$.

1987 Nutrition in the reproductive years. In Nutritional anthropology, edited by Francis E. Johnston, pp. 119-154. A. R. Liss, New York.

Anderson, H. L., N. J. Benevenga, and A. E. Harper

1968 Associations among food and protein intake, serine dehydratase, and plasma amino acids. American Journal of Physiology 214(5):1008-1013.

Bahuchet, Serge

n.d. Food sharing among the pygmies of central Africa. Unpublished paper presented at a conference on The Sharing of Food: From Phylogeny to History, Reimer Stifftung, Bad Homburg, Germany (1984).

Bailey, Robert C.

1988 The significance of hypergyny for understanding subsistence behaviour among contemporary hunters and gatherers. In Diet and subsistence: current archaeological perspectives, edited by B. V. Kennedy and G. M. LeMoine, pp. 57-65. Proceedings of the 19th Annual Chacmool Conference, University of Calgary Archaeological Association.

Barnard, Alan, and James Woodburn

1988 Property, power and ideology in hunter-gathering societies: an introduction. In Hunters and gatherers 2: property, power and ideology, edited by Tim Ingold, David Riches, and James Woodburn, pp. 4-31. Berg, Oxford.

Barnicott, N. A., F. J. Bennett, J. C. Woodburn, T. R. E. Pilkington, and A. Antonis

1972 Blood pressure and serum cholesterol in the Hadza of Tanzania. Human Biology 44(1):87-116.

Barthalmus, George T.

1980 Terrestrial organisms. In Introduction to environmental toxicology, edited by Frank E. Guthrie and Jerome J. Perry, pp. 106-119. Elsevier, New York.

\section{Begler, Elsie B.}

1978 Sex, status, and authority in egalitarian society. American Anthropologist 80:571-588.

Bentley, Gillian R.

1985 Hunter-gatherer energetics and fertility: a reassessment of the !Kung San. Human Ecology 13(1):79-109.

Binford, Lewis R.

1978 Nunamiut ethnoarchaeology. Academic Press, New York. 
1984 Butchering, sharing, and the archaeological record. Journal of Anthropological Archaeology 3:235-257.

Blurton Jones, $\mathrm{N}$.

1986 Bushman birth spacing: a test for optimal interbirth intervals. Ethology and Sociobiology 7:91-105.

Blurton Jones, Nicholas G., and R. M. Sibley

1978 Testing adaptiveness of culturally determined behavior: do Bushmen women maximize their reproductive success by spacing births widely and foraging seldom? In Human behaviour and adaptation, edited by Nicholas G. Blurton Jones and V. Reynolds, pp. 135-157. Society for the Study of Human Biology Symposium No. 18. Taylor and Francis, London.

Bogoras, Waldemar

1904-1909 The Jesup North Pacific expedition, Vol. VII. American Museum of Natural History, Memoir 11. (Reprinted by AMS Press, 1975.)

Bolton, J. M.

1972 Food taboos among the Orang Asli in west Malaysia: a potential nutritional hazard. American Journal of Clinical Nutrition 25:789-799.

Bongaarts, John

1980 Does malnutrition affect fecundity? a summary of evidence. Science 208:564 569.

Brooke, O. G.

1987 Nutritional requirements of low and very low birthweight infants. Annual Review of Nutrition 7:91-116.

Brooks, P. M., J. Hanks, and J. V. Ludbrook

1977 Bone marrow as an index of condition in African ungulates. South African Journal of Wildlife Research 7(2):61-66.

Buchanan, W. F.

1988 Shellfish in prehistoric diet: Elands Bay, S.W. Cape Coast, South Africa. BAR International Series 455. British Archaeology Reports, Oxford.

Bunn, Henry T., Laurence E. Bartram, and Ellen M. Kroll

1988 Variability in bone assemblage formation from Hadza hunting, scavenging, and carcass processing. Journal of Anthropological Archaeology 7:412-457.

Burkhardt, S. S., L. P. Mercer, M. R. Schweisthal, and T. B. Cole

1982 Kinetics of specific food intake and weight gain in rat. American Journal of Physiology 243:R531-R536.

Cahill, George F., Jr.

1986 The future of carbohydrates in human nutrition. Nutrition Reviews $44(2): 40-43$.

Calloway, D. H., and Sheldon Margen

1968 Human response to diets very high in protein. Federation Proceedings 27:725 [Abstract]

Campbell, Kenneth L., and James W. Wood

1988 Fertility in traditional societies. In Natural human fertility: social and biological determinants, edited by Peter Diggory, Malcolm Potts, and Sue Teper, pp. 39-69. Proceedings of the 23rd Annual Symposium of the Eugenics Society. Macmillan, London.

Cashdan, Elizabeth A.

1985 Coping with risk: reciprocity among the Basarwa of northern Botswana. Man 20(3):454-474.

Castonguay, T. W., W. J. Hartman, E. A. Fitzpatrick, and J. S.Stern

1982 Dietary self-selection and the Zucker rat. Journal of Nutrition 112:796-800. 
Cheremin, Ju. A.

1985 The influence of rations with an excess content of protein on nitrogen metabolism in men. Voprosy Pitaniia 6:16-21 [In Russian]

Connell, D. W., and G. J. Miller

1984 Chemistry and ecotoxicology of pollution. Wiley, New York.

Cowlishaw, Gillian

1981 The determinants of fertility among Australian Aborigines. Mankind 13(1):3755.

Dickens, G., and W. H. Trethowan

1971 Cravings and aversions during pregnancy. Journal of Psychosomatic Research 15:259-268.

Dickerson, O. B.

1980 Arsenic. In Metals in the environment, edited by H. A. Waldron, pp. 1-24. Academic Press, New York.

Donald, P., G. C. Pitts, and S. L. Pohl

1981 Body weight and composition in laboratory rats: effects of diets with high or low protein concentrations. Science 211:185-186.

Draper, H. H.

1977 The Aboriginal Eskimo diet in modern perspective. American Anthropologist 79:309-316.

1980 Nutrition. In The human biology of circumpolar populations, edited by F. A. Milan, pp. 257-284. International Biological Programme 21. Cambridge Univ. Press, Cambridge.

Dugdale, A. E., and Susan Lovell

1981 The effect of early growth on distribution of subcutaneous fat in Aboriginal children. Ecology of Food and Nutrition 11:53-55.

Eaton, S. B., and M. Konner

1985 Paleolithic nutrition: a consideration of its nature and current implications. New England Journal of Medicine 312(5):283-289.

Eidlitz, Kerstin

1969 Food and Emergency Food in the Circumpolar Area. Studia Ethnographica Upsaliensia 32. Almqvist and Wiksell, Uppsala, Sweden.

Ellison, P. T., N. R. Peacock, and C. Lager

1986 Salivary progesterone and luteal function in two low fertility populations of northeast Zaire. Human Biology 58:473-483.

1989 Ecology and ovarian function among Lese women of the Ituri Forest, Zaire. American Journal of Physical Anthropology 78:519-526.

Ferm, Vergil H.

1972 The teratogenic effects of metals on mammalian embryos. In Advances in teratology, edited by D. H. M. Woollam, Vol. 5, pp. 51-75. Academic Press, New York.

Flanagan, James G.

1989 Hierarchy in simple "egalitarian" societies. Annual Review of Anthropology 18:245-266.

Fried, Morton H.

1967 The evolution of political society. Random House, New York.

Galvin, Kathleen

1985 Food procurement, diet, activities and nutrition of Ngisonyoka, Turkana pastoralists in an ecological and social context. Unpublished Ph.D. Dissertation, Department of Anthropology, State University of New York, Binghamton. 
Gaulin, S. J. C., and M. Konner

1977 On the natural diet of primates, including humans. In Nutrition and the brain, edited by R. J. Wurtman and J. J. Wurtman, Vol. 1, pp. 1-86. Raven Press, New York.

Giffen, Naomi M.

1930 The roles of men and women in Eskimo culture. Univ. of Chicago Press, Chicago.

Goldman, H. I., J. S. Goldman, I. Kaufman, and O. B. Liebman

1974 Late effects of early dietary protein intake on low-birth-weight infants. Journal of Pediatrics 85(6):764-769.

Gould, Richard A.

1981 Comparative ecology of food-sharing in Australia and northwest California. In Omnivorous primates, edited by Robert S. O. Harding and Geza Teleki, pp. 422-454. Columbia Univ. Press, New York.

1982 To have and have not: the ecology of sharing among hunter-gatherers. In $R e$ source managers: North American and Australian hunter-gatherers, edited by Nancy M. Williams and Eugene S. Hunn, pp. 69-91. AAAS Selected Symposium No. 67. Westview, Boulder, CO.

Gould, Richard A., and P. J. Watson

1982 A dialogue on the meaning and use of analogy in ethnoarchaeological reasoning. Journal of Anthropological Archaeology 1:355-381.

Guthrie, Helen A.

1975 Introductory nutrition, 3rd ed., C. V. Mosby, St. Louis.

Harpending, H., and L.-A. Wandsnider

1982 Population structures of Ghanzi and Ngamiland !Kung. In Current developments in anthropological genetics, edited by M. H. Crawford and J. H. Mielke, Vol. 2, pp. 29-50. Plenum, New York.

Harper, Alfred E.

1974a Basic concepts. In Improvement of protein nutriture. National Research Council, Food and Nutrition Board, Committee on Amino Acids, pp. 1-22. National Academy of Sciences, Washington, DC.

1974b Effects of disproportionate amounts of amino acids. In Improvement of protein nutriture. National Research Council, Food and Nutrition Board, Committee on Amino Acids, pp. 138-166. National Academy of Sciences, Washington, DC.

Harper, Alfred E., and John C. Peters

1989 Protein intake, brain amino acid and serotonin concentrations and protein selfselection. Journal of Nutrition 119:677-689.

Harris, David R.

1978 Adaptation to a tropical rain-forest environment: Aboriginal subsistence in northeastern Queensland. In Human behaviour and adaptation, edited by N. G. Blurton Jones and V. Reynolds, pp. 113-134. Society for the Study of Human Biology Symposium No. 18. Taylor and Francis, London.

Hausman, Alice J., and Edwin N. Wilmsen

1985 Economic change and secular trends in the growth of San children. Human Biology 57(4):563-571.

Hayden, Brian

1981 Subsistence and ecological adaptations of modern hunter/gatherers. In Omnivorous primates, edited by R. S. O. Harding and Geza Teleki, pp. 344-421. Columbia Univ. Press, New York. 
Hayden, B., M. Deal, A. Cannon, and J. Casey

1986 Ecological determinants of women's status among hunter/gatherers. Human Evolution 1(5):449-474.

Hayes, Wayland J.

1975 Toxicology of pesticides. Williams and Wilkins, Baltimore, MD.

Hegsted, D. M.

1978 Protein-calorie malnutrition. American Scientist 66:61-65.

Hegsted, Maren, and Hellen M. Linkswiler

1981 Long-term effects of level of protein intake on calcium metabolism in young adult women. Journal of Nutrition 111:244-251.

Henry, Jules

1951 The economics of Pilaga food distribution. American Anthropologist 53:187219.

Hetzel, Basil S.

1978 The changing nutrition of Aborigines in the ecosystem of central Australia. In The nutrition of Aborigines in relation to the ecosystem of central Australia, edited by B. S. Hetzel and H. J. Frith, pp. 39-47. Symposium of the Commonwealth Scientific and Industrial Research Organization. CSIRO, Melbourne.

Hewlett, Barry S.

1988 Sexual selection and parental investment among Aka Pygmies. In Human reproductive behaviour: a Darwinian perspective, edited by L. Betzig, M. Borgerhoff Mulder, and P. Turke, pp. 263-276. Cambridge Univ. Press, Cambridge.

Hewlett, Barry S., J. M. H. van de Koppel, and L. L. Cavalli-Sforza

1982 Exploration ranges of Aka Pygmies of the central African Republic. Man (N.S.)17:418-430.

Hill, Kim

1988 Macronutrient modifications of optimal foraging theory: an approach using indifference curves applied to some modern foragers. Human Ecology 16(2):157197.

Hill, Kim, and A. Magdalena Hurtado

1989 Hunter-gatherers of the New World. American Scientist 77(5):437-443.

Hill, K., H. Kaplan, K. Hawkes, and A. M. Hurtado

1987 Foraging decisions among Ache hunter-gatherers: new data and implications for optimal foraging models. Ethology and Sociobiology 8:1-36.

Hitchcock, Robert K.

1986 Botswana: impacts of drought upon Kalahari San populations. International Work Group for Indigenous Affairs Newsletter (Copenhagen) 45:9-14.

Ho, K.-J., K. Biss, B. Mikkelson, L. A. Lewis, and C. B. Taylor

1971 The Masai of east Africa: some unique biological characteristics. Archives of Pathology 91(5):387-410.

Hook, Ernest B.

1978 Dietary cravings and aversions during pregnancy. American Journal of Clinical Nutrition 31:1355-1362.

Howell, Nancy

1979 Demography of the Dobe !Kung. Academic Press, New York.

1986 Feedbacks and buffers in relation to scarcity and abundance: studies of huntergatherer populations. In The state of population theory: forward from Malthus, edited by David Coleman and Roger Schofield, pp. 156-187. Basil Blackwell, Oxford. 
Høygaard, Arne

1940 Studies on the nutrition and physio-pathology of Eskimos, undertaken at Angmagssalik, East-Greenland 1936-1937. Norsk Videnskapsakademi i Oslo, Skrifter 1. Matematisk-Naturvidenskapelig Klasse 1940(9):1-176.

Hunn, Eugene S.

1981 On the relative contribution of men and women to subsistence among huntergatherers of the Columbia Plateau: a comparison with Ethnographic Atlas summaries. Journal of Ethnobiology 1(1):124-134.

Hurtado, A. Magdalena, and Kim Hill

1987 Early dry season subsistence ecology of Cuiva (Hiwi) foragers of Venezuela. Human Ecology 15(2): 163-187.

Huss-Ashmore, Rebecca

1980 Fat and fertility: demographic implications of differential fat storage. Yearbook of Physical Anthropology 23:65-91.

Ichikawa, $M$.

1983 An examination of the hunting-dependent life of the Mbuti Pygmies, eastern Zaire. Kyoto University African Studies Monograph 4:55-76.

Isaac, Glynn Ll.

1978 The food-sharing behavior of protohuman hominids. Scientific American 238(4):90-108.

Jochim, Michael A.

1981 Strategies for survival: cultural behavior in an ecological context. Academic Press, New York.

Kaberry, Phyllis M.

1973 Aboriginal woman. Gordon Press, New York.

Kaplan, Hillard, and Kim Hill

1985a Hunting ability and reproductive success among male Ache foragers: preliminary results. Current Anthropology 26(1):131-133.

1985b Food sharing among Ache foragers: tests of explanatory hypotheses. Current Anthropology 26(2):223-246.

Kaplan, Hillard, Kim Hill, and A. Magdalena Hurtado

1990 Risk, foraging and food sharing among the Ache. In Risk and uncertainty in tribal and peasant economies, edited by Elizabeth Cashdan, pp. 107-144. Westview, Boulder, CO.

Kerr-Grieve, J. F., B. Mary Campbell-Brown, and F. D. Johnstone

1979 Dieting in pregnancy: a study of the effect of a high protein low carbohydrate diet on birthweight on an obstetric population. In International Colloquium on Carbohydrate Metabolism in Pregnancy and the Newborn 1978, edited by H. W. Sutherland and J. M. Stowers, pp. 518-534. Springer-Verlag, New York.

Kirkpatrick, Roy $\mathbf{L}$.

1980 Physiological indices in wildlife management. In Wildlife management techniques manual, 4th ed., revised, edited by S. D. Schemnitz, pp. 99-112. The Wildlife Society, Washington, DC.

Knauft, Bruce $M$.

1987 Reconsidering violence in simple human societies. Current Anthropology 28(4):457-500.

Konner, M., S. Boyd Eaton, and Marjorie Shostak

n.d. Paleolithic biology and modern diet: adaptation or confrontation. Paper presented at the Annual Meeting of the American Association for the Advancement of Science, Boston, Massachusetts, Feb. 13, 1988. 
Konner, M., and M. Shostak

1987 Timing and management of birth among the !Kung: biocultural interaction in reproductive adaptation. Cultural Anthropology 2(1):11-28.

Krehl, W. A., and J. J. Barboriak

1960 Factors affecting utilization of food nutrients by the normal organism. In $\mathrm{Nu}$ tritional evaluation of food processing, edited by $\mathbf{R}$. S. Harris and $\mathrm{H}$. von Loesecke, pp. 521-540. Wiley, New York.

Krogh, August, and Marie Krogh

1914 A study of the diet and metabolism of Eskimos undertaken in 1908 on an expedition to Greenland. Meddelelser om Groenland 51(1):1-52.

Lager, C., and P. T. Ellison

1987 Effects of moderate weight loss on ovulatory frequency and luteal function in adult women. American Journal of Physical Anthropology 72(2):221-222.

Lansdown, A. B. G.

1983 Teratogenicity and reduced fertility resulting from factors present in food. In Toxic hazards in food, edited by D. M. Conning and A. B. G. Lansdown, pp. 73-121. Raven Press, New York.

Lechtig, Aaron, et al.

1978 Effect of maternal nutrition on infant mortality. In Nutrition and human reproduction, edited by W. Henry Mosley, pp. 147-174. Plenum, New York.

Ledger, H. P.

1968 Body composition as a basis for a comparative study of some east African mammals. Symposia of the Zoological Society of London 21:289-310.

Lee, Richard B.

1979 The !Kung San: men, women, and work in a foraging society. Cambridge Univ. Press, Cambridge.

1982 Politics, sexual and non-sexual, in an egalitarian society. In Politics and history in band societies, edited by Eleanor R. Leacock and Richard B. Lee, pp. 37-59. Cambridge Univ. Press, Cambridge.

Lee, Richard B., and Irven DeVore (Eds.)

1968 Man the hunter. Aldine, Chicago.

Leidy, R. B.

1980 Aquatic organisms. In Introduction to environmental toxicology, edited by Frank E. Guthrie and Jerome J. Perry, pp. 120-134. Elsevier, New York.

Lemon, Peter W. R., Kevin E. Yarasheski, and Dennis G. Dolny

1984 The importance of protein for athletes. Sports Medicine 1:474-484.

Little, M. A., K. Galvin, K. Shelley, B. R. Johnson, Jr., and M. Mugambi

1988 Resources, biology and health of pastoralists. In Arid lands: today and tomorrow, edited by E. E. Whitehead, C. F. Hutchinson, B. N. Timmerman, and R. G. Varady, pp. 713-726. Westview, Boulder, CO.

Loudon, Andrew

1987 Nutritional effects on puberty and lactational infertility in mammals: some interspecies considerations. Proceedings of the Nutrition Society 46:203-216.

Luckey, T. D., and B. Venugopal

1977 Metal toxicity in mammals, Vol. 1. Plenum, New York.

Lumholtz, C.

1889 Among cannibals. John Murray, London.

Lunn, Peter G.

1988 Malnutrition and fertility. In Natural human fertility: social and biological determinants, edited by Peter Diggory, Malcolm Potts, and Sue Teper, pp. 135- 
152. Proceedings of the 23rd Annual Symposium of the Eugenics Society. Macmillan, London.

Mann, George V., et al.

1962 The health and nutritional status of Alaskan Eskimos. American Journal of Clinical Nutrition 11:31-76.

Marshall, Lorna

1976 The !Kung of Nyae Nyae. Harvard Univ. Press, Cambridge, MA.

Martorell, Reynaldo, and Teresa Gonzalez-Cossio

1987 Maternal nutrition and birth weight. Yearbook of Physical Anthropology 30:195220.

McArdle, William D., Frank I. Katch, and Victor L. Katch

1986 Exercise physiology: energy, nutrition, and human performance. Lea and Febiger, Philadelphia.

McClellan, W. S., and E. F. DuBois

1930 Clinical calorimetry. XLV. Prolonged meat diets with a study of kidney function and ketosis. Journal of Biological Chemistry 87(3):651-668.

McClellan, W. S., V. R. Rupp, and V. Toscani

1930 Clinical calorimetry. XLVI. Prolonged meat diets with a study of the metabolism of nitrogen, calcium, and phosphorus. Journal of Biological Chemistry 87(3):669-680.

McGilvery, Robert W.

1983 Biochemistry: a functional approach, 3rd ed. W. B. Saunders, Philadelphia.

Mead, James F., R. B. Alfin-Slater, D. R. Howton, and G. Popjak

1986 Lipids: chemistry, biochemistry, and nutrition. Plenum, New York.

Mercer, L. P., D. F. Watson, and J. S. Ramlet

1981 Control of food intake in the rat by dietary protein concentration. Journal of Nutrition 111:1117-1123.

Metz, J., D. Hart, and H. C. Harpending

1971 Iron, folate, and vitamin $B_{12}$ nutrition in a hunter-gatherer people: a study of the !Kung Bushmen. American Journal of Clinical Nutrition 24:229-242.

Miller, Donald R.

1984 Chemicals in the environment. In Effects of pollutants at the ecosystem level, edited by P. J. Sheehan, D. R. Miller, G. C. Butler, and Ph. Bourdeau, pp. 7-14. Scientific Committee on Problems of the Environment (SCOPE) 22. Wiley, New York.

Miller, Sanford A., and Geraldine V. Mitchell

1982 Optimisation of human protein requirements. In Food proteins, edited by P. F. Fox and J. J. Condon, pp. 105-120. Applied Science, London.

Moriarity, F.

1983 Ecotoxicology: the study of pollutants in ecosystems. Academic Press, New York.

Munro, H. N.

1964 General aspects of the regulation of protein metabolism by diet and by hormones. In Mammalian protein metabolism, edited by H. N. Munro and J. B. Allison, Vol. 1, pp. 381-481. Academic Press, New York.

National Academy of Sciences

1985 Preventing low birthweight. Committee to Study the Prevention of Low Birthweight, Division of Health Promotion and Disease Prevention, Institute of Medicine. National Academy Press, Washington, DC. 
Nickerson, N. H., N. H. Rowe, and E. A. Richter

1973 Native plants in the diets of north Alaskan Eskimos. In Man and his foods, edited by C. Earle Smith, Jr., pp. 3-27. University of Alabama Press, University, AL.

Noli, Dieter, and Graham Avery

1988 Protein poisoning and coastal subsistence. Journal of Archaeological Science 15:395-401.

O'Connell, James F., K. Hawkes, and N. Blurton Jones

1988 Hadza scavenging: implications for Plio/Pleistocene hominid subsistence. Current Anthropology 29:356-363.

O'Connell, James F., and Brendan Marshall

1989 Analysis of kangaroo body part transport among the Alyawara of central Australia. Journal of Archaeological Science 16:393-405.

Oddoye, E. Aban, and Sheldon Margen

1979 Nitrogen balance studies in humans: long-term effect of high nitrogen intake on nitrogen accretion. Journal of Nutrition 109:363-377.

Olson, James A.

1988 Vitamin A, retinoids, and carotenoids. In Modern nutrition in health and disease, 7th ed., edited by Maurice E. Shils and Vernon R. Young, pp. 292-312. Lea and Febiger, Philadelphia.

Payne, P. R.

1975 Safe protein-calorie ratios in diets: the relative importance of protein and energy intake as causal factors in malnutrition. American Journal of Clinical Nutrition 28:281-286.

Pellett, Peter L., and Vernon R. Young

1988 Protein and amino acid needs for adults. Ecology of Food and Nutrition 21:321330.

Pennington, Renee, and Henry Harpending

1988 Fitness and fertility among Kalahari !Kung. American Journal of Physical Anthropology 77:303-319.

Peters, J. C., D. J. Nemetz, J. K. Tews, and A. E. Harper

1983 Relationships among plasma and brain amino acid patterns and protein intake. Nutrition Reports International 27(2):407-419.

Peterson, R. O., D. L. Allen, and J. M. Dietz

1982 Depletion of bone marrow fat in moose and a correction for dehydration. Journal of Wildlife Management 46(2):547-551.

Plath, C., W. Heine, L. Krienke, I. Richter, K. Wutzke, J. Towe, and K. Krawielitzki

$1985{ }^{15} \mathrm{~N}$-tracer-kinetic studies on the nitrogen metabolism of very small preterm infants on a diet of mother's milk. Human Nutrition: Clinical Nutrition 39C:399 409.

Profet, Margie

n.d. Pregnancy sickness as adaptation: a deterrent to maternal ingestion of teratogens. In The adapted mind: evolutionary psychology and the generation of culture, edited by Jerome Barkow, Leda Cosmides, and John Tooby (in press).

Ratcliffe, Philip R.

1980 Bone marrow fat as an indicator of condition of Roe deer. Acta Theriologica 25(26):333-340.

Reich, Allen

1981 Sequential mobilization of marrow fat in the impala (Aepyceros melampus) and analysis of condition of wild dog (Lycaon pictus) prey. Journal of Zoology (London) 194:409 419. 
Reilly, Conor

1980 Metal contamination of food. Applied Science, London.

Rosenberg, E. $\mathbf{M}$.

1980 Demographic effects of sex-differential nutrition. In Nutritional anthropology: contemporary approaches to diet \& culture, edited by N. W. Jerome, R. F. Rush, David Kandel, and G. H. Pelto, pp. 181-203. Redgrave, Pleasantville, New York.

1982 Effects of changes in protein and calorie intake during pregnancy on the growth of the human fetus. In Effectiveness and satisfaction in antenatal care, edited by Murray Enkin and Iain Chalmers, pp. 92-113. Clinics in Developmental Medicine Nos. 81/82. J. B. Lippincott, Philadelphia.

1986 Nutrition in the preparation for pregnancy. In Pregnancy care: a manual for practice, edited by G. Chamberlain and J. Lumley, pp. 113-139. Wiley, New York.

1989 Effects of changes in protein and calorie intake during pregnancy on the growth of the human fetus. In Effective care in pregnancy and childbirth, edited by $\mathbf{I}$. Chalmers, M. Enkin, and M. J. N. C. Keirse, Vol, 1, pp. 255-280. Oxford Univ. Press, Oxford.

Rush, David, Zena Stein, and Mervyn Susser

1980 A randomized controlled trial of prenatal nutritional supplementation in New York City. Pediatrics 65(4):683-697.

Sahlins, Marshall

1968 Notes on the original affluent society. In Man the hunter, edited by R. B. Lee and I. DeVore, pp. 85-89. Aldine, Chicago.

Scrimshaw, Nevin S., and Vernon R. Young

1976 The requirements of human nutrition. Scientific American 235(3):51-64.

Service, Elman R.

1971 Primitive social organization, 2nd ed. Random House, New York.

1988 Modern nutrition in health and disease, 7th ed., edited by Shills, Maurice E., and Vernon R. Young. Lea and Febiger, Philadelphia.

Shorland, F. B.

1988 Is our knowledge of human nutrition soundly based? World Review of Nutrition and Dietetics 57:126-213.

Silberbauer, George B.

1981 Hunter and habitat in the central Kalahari. Cambridge Univ. Press, Cambridge. Sinclair, A. R. E.

1974 The natural regulation of buffalo populations in east Africa. IV. The food supply as a regulating factor, and competition. East African Wildlife Journal 12:291311.

1975 The resource limitation of trophic levels in tropical grassland ecosystems. Journal of Animal Ecology 44:497-520.

Sinclair, A. R. E., and P. Duncan

1972 Indices of condition in tropical ruminants. East African Wildlife Journal 10:143149.

Sinclair, H. M.

1953 The diet of Canadian Indians and Eskimos. Proceedings of the Nutrition Society 12:69-82.

Siskind, Janet

1973 To hunt in the morning. Oxford Univ. Press, New York.

Sloan, Nancy L.

1985 Effects of maternal protein consumption on fetal growth and gestation. Unpub- 
lished Doctor of Public Health Dissertation, Faculty of Medicine, Columbia University, New York.

Smuts, Barbara

1985 Sex and friendship in baboons. Aldine, Hawthorne, NY.

Spallholz, J. E., J. L. Martin, and H. E. Ganther (Eds.)

1981 Selenium in biology and medicine. AVI, Westport, CT. Speth, John D.

1983 Bison kills and bone counts: decision making by ancient hunters. Univ. of Chicago Press, Chicago.

1987a Early hominid subsistence strategies in seasonal habitats. Journal of Archaeological Science 14(1):13-29.

1987b Les stratégies alimentaires des chasseurs-cueilleurs. La Recherche 18(190):894 903.

1988 Nutritional aspects of food sharing in egalitarian foraging societies. In Diet and subsistence: current archaeological perspectives, edited by B. V. and G. M. LeMoine, pp. 108-114. Proceedings of the 19th Annual Chacmool Conference, University of Calgary Archaeological Association.

1989 Early hominid hunting and scavenging: the role of meat as an energy source. Journal of Human Evolution 18(4):329-343.

Speth, John D., and Katherine A. Spielmann

1983 Energy source, protein metabolism and hunter-gatherer subsistence strategies. Journal of Anthropological Archaeology 2:1-31.

Spielmann, Katherine A.

1988 Female food taboos and fertility in hunter-gatherer societics. In Diet and subsistence: current archaeological perspectives, edited by B. V. Kennedy and G. M. LeMoine, pp. 115-122. Proceedings of the 19th Annual Chacmool Conference, University of Calgary Archaeological Association.

1989 A review: dietary restrictions on hunter-gatherer women and the implications for fertility and infant mortality. Human Ecology 17(3):321-345.

Stefansson, Vilhjalmur

1944 Arctic manual. Macmillan, New York.

1956 The fat of the land. Macmillan, New York.

Stini, William A.

1981 Body composition and nutrient reserves in evolutionary perspective. In Food, nutrition and evolution: food as an environmental factor in the genesis of human variability, edited by D. N. Walcher and N. Kretchmer, pp. 107-120. Masson, New York.

Street, J. C., and R. P. Sharma

1977 Accumulation and release of chemicals by adipose tissue. In Handbook of physiology, Section 9. Reactions to environmental agents, edited by D. H. K. Lee, pp. 483-493. American Physiological Society, Bethesda, MD.

Tanaka, Jiro

1980 The San hunter-gatherers of the Kalahari: a study in ecological anthropology. Univ. of Tokyo Press, Tokyo.

Taylor, C. Bruce, and Kang-Jey Ho

1971 Studies on the Masai. American Journal of Clinical Nutrition 24:1291-1293.

Tierson, F. D., C. L. Olsen, and E. B. Hook

1985 Influence of cravings and aversions on diet in pregnancy. Ecology of Food and Nutrition 17:117-129.

Tobias, P. V.

1962 On the increasing stature of the Bushmen. Anthropos 57:801-810. 
Truswell, A. S.

1977 Diet and nutrition of hunter-gatherers. In Health and disease in tribal societies. Ciba Foundation Symposium 49 (N.S.), pp. 213-226. Elsevier, Amsterdam.

Truswell, A. S., and J. D. L. Hansen

1976 Medical research among the !Kung. In Kalahari hunter-gatherers, edited by R. B. Lee and I. DeVore, pp. 166-194. Harvard Univ. Press, Cambridge, MA. Underwood, E. J.

1973 Trace elements. In Toxicants occurring naturally in foods, 2nd ed., pp. 43-87. Committee on Food Protection, Food and Nutrition Board, National Research Council, National Academy of Sciences, Washington, DC.

Waal, Frans de

1982 Chimpanzee politics. Harper and Row, New York.

1989a Peacemaking among primates. Harvard Univ. Press, Cambridge, MA.

$1989 \mathrm{~b}$ Food sharing and reciprocal obligations among chimpanzees. Journal of Human Evolution 18:433-459.

Walker, Phillip L., and Barry S. Hewlett

n.d. Dental health, diet and social organization among central African Pygmies and Bantu. Paper Presented at the 86th Annual Meeting of the American Anthropological Association, Chicago, Illinois, Nov. 19, 1987.

Webb, Stephen

1988 Prehistoric stress in Australian Aborigines: a palaeopathological study of a hunter-gatherer population. BAR International Series 490. British Archaeology Reports, Oxford.

Wehmeyer, A. S., R. B. Lee, and Marjorie Whiting

1969 The nutrient composition and dietary importance of some vegetable foods eaten by the !Kung Bushmen. South African Medical Journal 43:1529-1530.

White, Neville

1985 Sex differences in Australian Aboriginal subsistence: possible implications for the biology of hunter-gatherers. In Human sexual dimorphism, edited by J. Ghesquiere, R. D. Martin, and F. Newcombe, pp. 323-361. Symposia of the Society for the Study of Human Biology 24. Taylor and Francis, London.

Whitney, E. N., and E. M. N. Hamilton

1984 Understanding nutrition, 3rd ed. West, St. Paul, MN.

Wiens, John A.

1977 On competitive and variable environments. American Scientist 65:590-597.

Wiessner, Polly

1977 Hxaro: a regional system of reciprocity for reducing risk among the !Kung San. Unpublished Ph.D. Dissertation, Department of Anthropology, University of Michigan, Ann Arbor.

1981 Measuring the impact of social ties on nutritional status among the !Kung San. Social Science Information (SAGE, London and Beverly Hills) 20(4-5):641-678.

1982 Risk, reciprocity and social influence on !Kung San economics. In Politics and history in band societies, edited by Eleanor R. Leacock and Richard B. Lee, pp. 61-84. Cambridge Univ. Press, London.

Wilmsen, Edwin N.

1978 Seasonal effects of dietary intake on Kalahari San. Federation Proceedings 37:65-72.

1982 Studies in diet, nutrition, and fertility among a group of Kalahari Bushmen in Botswana. Social Science Information (SAGE, London and Beverly Hills) 21(1):95-125.

1986 Biological determinants of fecundity and fecundability: an application of Bon- 
gaarts' model to forager fertility. In Culture and reproduction: an anthropological critique of demographic transition theory, edited by W. Penn Handwerker, pp. 59-89. Westview, Boulder, CO.

Wilmsen, Edwin N., and D. Durham

1988 Food as a function of seasonal environment and social history. In Coping with uncertainty in food supply, edited by I. de Garine and G. A. Harrison, pp. 52-87. Clarendon, Oxford.

Wilson, James G.

1977a Current status of teratology: general principles and mechanisms derived from animal studies. In Handbook of teratology, edited by James G. Wilson and F. Clarke Fraser, pp. 47-74. Plenum, New York.

1977b Environmental chemicals. In Handbook of teratology, edited by James G. Wilson and F. Clarke Fraser, pp. 357-385. Plenum, New York.

Winick, Myron

1989 Nutrition, pregnancy, and early infancy. Williams and Wilkins, Baltimore, MD.

Winterhalder, Bruce

1986 Diet choice, risk, and food sharing in a stochastic environment. Journal of Anthropological Archaeology 5:369-392.

World Health Organization

1972 Evaluation of mercury, lead, cadmium and the food additives amaranth, diethylpyrocarbonate, and octyl gallate. WHO Food Additives Series 4. World Health Organization, Geneva.

Worthington-Roberts, Bonnie, and Sue Rodwell Williams

1989 Nutrition in pregnancy and lactation, 4th ed. Times Mirror/Mosby, St. Louis, MO.

Wray, Joe D.

1978 Maternal nutrition, breast-feeding and infant survival. In Nutrition and human reproduction, edited by W. Henry Mosley, pp. 197-229. Plenum, New York.

Yellen, John E.

1977 Cultural patterning in faunal remains: evidence from the !Kung Bushmen. In Experimental archaeology, edited by D. Ingersoll, J. E. Yellen, and W. Macdonald, pp. 271-331. Columbia Univ. Press, New York. 